\title{
Spór przemyskiej kapituły katedralnej ze szlachtą o dziesięcinę biskupią w drugiej połowie XVI wieku
}

Zarys treści: W drugiej połowie XVI w. doszło w diecezji przemyskiej do sporu miejscowej
szlachty z kapitułą katedralną na tle zatrzymania przysługującej jej dziesięciny biskupiej, zwa-
nej biskupczyzną. Dziesięcina ta, będąca zryczałtowanym ekwiwalentem dziesięciny snopowej
z ról kmiecych, została nadana kapitule przez biskupów na przełomie XIV i XV w. W procesach
sądowych, rozpoczętych w 1590 r., szlachta, wykorzystując różne argumenty natury prawnej,
historycznej, a także retorykę protestancką, starała się zakwestionować prawa kapituły. Po
pięciu latach sporu Trybunał Koronny przyznał ostatecznie rację stronie kościelnej. Był to
ostatni na Rusi Czerwonej poważniejszy spór szlachty z Kościołem katolickim o dziesięciny.

Content outline: In the second half of the 16th century the Przemyśl diocese witnessed a dispute of local nobility with the cathedral chapter concerning the retention of their episcopal tithe, known as the bishop's share. That tithe, being the lump equivalent of the sheaf tithe from peasants' fields, was granted to the chapter by bishops at the turn of the $14^{\text {th }}$ and $15^{\text {th }}$ centuries. During court cases, started in 1590, the nobles, using a variety of legal and historical arguments, as well as Protestant rhetoric, tried to question the chapter's rights. After five years of the dispute, the Crown Tribunal decided that the church side was right. It was the last serious argument between local nobility and the Catholic Church over tithes in Red Ruthenia.

Słowa kluczowe: Kościół, dziesięcina biskupia, kapituła, reformacja, szlachta, Ruś, Przemyśl Keywords: Church, episcopal tithe, chapter, Reformation, nobility, Ruthenia, Przemyśl

W 1590 r. kapituła katedralna przemyska wniosła do sądu ziemskiego w Przeworsku dwadzieścia sześć spraw przeciwko szlachcie zamieszkującej zachodnią część ziemi przemyskiej o wstrzymaną od siedmiu lat, łącznie z pięciu miast i pięćdziesięciu ośmiu wsi, dziesięcinę biskupią, zwaną też biskupczyzną, episcopalia lub resta episcopalium ${ }^{1}$. Świadczenie to stanowiło główny element uposażenia kapituły, a było nadawane przez miejscowych biskupów etapami, od końca XIV do pierwszej połowy XV w. ${ }^{2}$ Sięgało zatem samych początków diecezji przemyskiej, podstaw jej

${ }^{1}$ Центральний державний історичний архів України Львів, fond 12, opis 1 (dalej cyt.: Przeworsk Z.) 36, s. 111-112, 337-344, 401-404, 629-631, 645-646.

${ }^{2}$ Uposażenie kapituły katedralnej przemyskiej nie doczekało się dotąd swojej monografii. Jedynie na marginesie swych dociekań wspominali o nim m.in.: J. F e d e r k i e w i c z, Kapituła przemyska ob. łac., Kronika Diecezji Przemyskiej 8-13, 1908-1913; T. Ś 1 i w a, Kolegium prałatów i kanoników rzymskokatolickiej kapituły przemyskiej w latach 1500-1525, Przemyśl 2016, s. 31-41 (z błędami); T. M. Tr a j d o s, Kapituła katedry przemyskiej i kuria biskupia 
funkcjonowania oraz wczesnego etapu kształtowania się na jej terenie sieci parafialnej. Mimo, że tak istotne dla Kościoła łacińskiego na Rusi Czerwonej, świadczenie to nie było dotąd przedmiotem większego zainteresowania badaczy ${ }^{3}$. Konieczne jest zatem bliższe scharakteryzowanie tej powinności.

Dziesięcina ta była jednym z trzech podstawowych obciążeń katolickiej ludności Rusi Czerwonej na rzecz Kościoła łacińskiego. Przysługiwała z mocy prawa kanonicznego biskupom ordynariuszom i mogła być przez nich ustępowana innym instytucjom kościelnym na terenie diecezji ${ }^{4}$. Oprócz niej wierni oddawali swym plebanom z tytułu posługi duszpasterskiej meszne ${ }^{5}$. Plebani pobierali też zwykle dziesięcinę z folwarków i ogrodów, choć nie było to uregulowane żadnym ogólnym przywilejem ani zwyczajem ${ }^{6}$. Ludność uiszczała też mniejsze opłaty, tzw. akcydensy, jak np. klerykatura, kolęda czy stołowe (mensalia). Biskupczyzna płacona była corocznie na św. Marcina (11 listopada) z każdego łanu oczynszowanego ${ }^{7}$. Początkowo, jak dowiadujemy się z nieco późniejszych dokumentów z końca XIV w., na mocy nieznanego nam dziś przywileju Kazimierza Wielkiego świadczona była w zróżnicowanej wysokości: 4, 6, 8 lub 12 szerokich groszy praskich (nonnulle tamen persone civitatis et diocesis predictarum pretextu cuiusdam privilegii clare memorie Kazimiri regis Polonie - - indulti, quidam videlicet ex eis, loco decime pro uno manso arabili et fructifero duodecim, alii vero octo et ceteri alii sex, et quamplures alii quatuor grossos polonicales - - persolvunt $)^{8}$. W XVI w. płacono już ją w jednolitym wymiarze

w czasach Władysława Jagiełły, Przegląd Historyczny 88, 1997, s. 383-415; G. K 1 e b o w i c z, Organizacja parafialna diecezji przemyskiej obrządku łacińskiego w XIV-XVI wieku, Lublin 2013, s. 94-96 (tutaj pełne zestawienie wcześniejszej literatury).

${ }^{3} \mathrm{O}$ pobieraniu przez biskupów na Rusi dziesięciny z ról kmiecych w pieniądzu jako pierwszy wspomniał W. A b r a ha m, Powstanie organizacji Kościoła łacińskiego na Rusi, t. I, Lwów 1904, s. 320-322; marginalnie wzmiankuje o tym G. K 1 e b o w i c z, Organizacja, s. 89. Nie wspominają o tej specyfice: S. Ch [ o d yń s k i], Dziesięcina w Polsce, w: Encyklopedia kościelna, red. M. Nowodworski, t. IV, Warszawa 1874, s. 477-490; J. D u d z i a k, Dziesięcina, w: Encyklopedia katolicka, t. IV, Lublin 1985, kol. 600-603; M. W y s z y ń s k i, Ze studiów nad historią dziesięciny w Polsce średniowiecznej, t. I: Czasy Władysława Łokietka i Kazimierza W., Lwów 1929.

4 S. Ch [ o d y ńs ki], Dziesięcina w Polsce, s. 480.

5 J. Mat us zew s ki, Missalia - mensalia, w: Cultus et cognitio. Studia z dziejów średniowiecznej kultury, Warszawa 1976, s. 373-391. Warto podkreślić, że wbrew starszej literaturze, świadczenie to wcale nie było nieznaczne (tamże, s. 374). W rzeczywistości wartość mesznego, ustalona na 1 kłodę żyta i 1 kłodę owsa z łanu, stanowiła rzeczywistą dziesiątą część plonów (Akta grodzkie i ziemskie z czasów Rzeczypospolitej Polskiej z Archiwum tak zwanego Bernardyńskiego we Lwowie, t. I-XXV, Lwów 1868-1935 [dalej cyt.: AGZ], tu t. XIII, nr 5327: quatuor laneos unacum frumento computando siliginis XL truncos).

${ }^{6}$ AGZ IV, nr 12 (1406): Decimas vero praediales vel minutas eisdem curatis, sacerdotibus seu ecclesiarum parochialium rectoribus tollendi et recipiendi neque ex privilegio, neque ex aliqua conswetudine locorum predictorum facultas atributa est aut potestas. W. A b r a h a m, Powstanie, s. 322-323, zinterpretował ten fragment dokumentu biskupa Macieja jako zwolnienie z tzw. dziesięciny mniejszej (z ogrodów), co wydaje się nieścisłe.

7 W. A b r a h a m, Powstanie, s. 320: „Podstawą bytu kościoła łacińskiego w ziemi czerwonoruskiej były głównie nowe osady i lokacje”.

${ }^{8}$ AGZ VIII, nr 24 (1395), 26 (1397). To zróżnicowanie wysokości dziesięciny było być może wynikiem rozciągnięcia na Ruś ustaleń ugody Kazimierza Wielkiego z biskupem 
6 szerokich groszy praskich z łanu. Według Władysława Abrahama dziesięcina na Rusi była niższa niż w innych ziemiach Korony, gdyż Kazimierz Wielki, ,starając się o to, aby jak najwięcej osadników ściągnąć na Ruś Czerwoną, ów znaczny ciężar, jakiem było opłacanie dziesięciny, w sposób dość daleko idący złagodził"9. Ulga ta spowodowana była też trudnościami wynikającymi z niedawnej inkorporacji tych odmiennych kulturowo i konfesyjnie ziem, koniecznością ich obrony oraz budowy tam od podstaw struktur państwowych i kościelnych ${ }^{10}$. Snopowa dziesięcina z łanów kmiecych, przysługująca biskupom w innych diecezjach, nie była więc tutaj, jak zauważył W. Abraham, w ogóle w użyciu' ${ }^{11}$.

Obowiązkowi płacenia dziesięcin nie podlegali początkowo dominujący na Rusi wyznawcy religii prawosławnej (scismatici, Roxolani), z wyjątkiem sytuacji, kiedy wchodzili oni w posiadanie ról użytkowanych wcześniej przez katolików. Podlegać mu miały natomiast grunty przejęte $\mathrm{z}$ czasem $\mathrm{z}$ rąk prawosławnych przez katolików ${ }^{12}$. Biskupczyznę płacono natomiast także z wsi nowo lokowanych oraz z nowizn (de novalibus universis $)^{13}$, z których dziesięciny, zgodnie z prawem kanonicznym, przysługiwały biskupom (pro episcopali mensa de iure communi debentur), wreszcie z łanów kmiecych włączonych wtórnie do folwarków szlacheckich.

Kapituła pobierała zatem z nadania biskupiego dziesięciny z wszystkich osad (poza tymi zamieszkałymi przez Rusinów oraz tymi nielicznymi, z których dziesięciny wcześniej już przekazane zostały innym odbiorcom) na pewnych obszarach,

krakowskim Bodzętą z 14 VII 1359 r., w wyniku której najwyższą stawkę, tj. 1 wiardunek (12 groszy), płacili osadnicy po ustaniu wolnizny z każdego łanu (libertate expleta de quolibet manso parvo sive magno, locato sive locando, ferto grossorum) w nowo lokowanych osadach, ich sołtysi i wójtowie zaś - po 3 skojce (6 groszy). Sołtysi w osadach dawnych, z których uiszczano już dziesięcinę snopową, mieli odtąd płacić po 8 groszy (Ioannis Dlugossi Annales seu cronicae incliti Regni Poloniae, lib. IX, Warszawa 1978, s. 294-299; Kodeks dyplomatyczny Małopolski, wyd. F. Piekosiński, t. III, Kraków 1887, nr 730; M. W y s z y ń s k i, Ze studiów, s. 61, 67, 69, 70-71). Przykładowo na terenie Rusi dziesięcinę w wysokości 4 skojców (8 groszy) niewskazanemu odbiorcy mieli płacić po ustaniu wolnizny mieszczanie z Wiszni na mocy przywileju lokacyjnego Kazimierza Wielkiego z 26 III 1368 r. (Kodeks dyplomatyczny Małopolski, t. III, nr 812; G. K l e b o w i c z, Organizacja, s. 338). Z kolei mieszczanie z Tyczyna według aktu lokacyjnego z 14 III 1368 r. mieli płacić określonemu w przyszłości odbiorcy (cui de iure debuerint) dziesięcinę w wysokości 2 skojców (4 groszy) z łanu, a miejscowemu plebanowi - meszne (Kodeks dyplomatyczny Małopolski, t. I, Kraków 1876, nr 360). W obu wypadkach przyszłym odbiorcą dziesięcin miał być niewątpliwie biskup.

9 W. A brah a m, Powstanie, s. 321.

10 Tamże, s. 321-322; H. P a s z k i e w i c z, Polityka ruska Kazimierza Wielkiego, Warszawa 1925, s. 251-272; M. Wy s z y ń s ki, Ze studiów, s. 70-71; Z. K a c z m a r c z y k, Monarchia Kazimierza Wielkiego, t. II, Poznań 1946, s. 102-103; J. K u r t y k a, Osadnictwo średniowieczne. Początki osady i miasta, w: Dzieje Rzeszowa, t. I, Rzeszów 1994, s. 124.

${ }^{11}$ W. A brah a m, Powstanie, s. 322.

12 AGZ VIII, nr 34 (1406): ac decimas post omnes et singulos agros, quos nunc Rutheni et alii scismatici colunt et occupant, in futurum per christifideles disponente domino collendos et possidendos. J. K u r t y k a, Osadnictwo, s. 145, zauważył w spisie wsi okręgu rzeszowskiego objętych obowiązkiem dziesięcinnym na rzecz kapituły przemyskiej brak pewnych istniejących wcześniej wsi i wskazał na fakt istnienia w nich cerkwi, a zatem zamieszkiwania ich przez ludność prawosławną, niepodlegającą obowiązkowi dziesięcinnemu wobec biskupów katolickich.

13 AGZ VIII, nr 22, 34; S. C h [ o d y ń s k i], Dziesięcina w Polsce, s. 482-483. 
skupionych w zachodniej części diecezji. Obszary te określane były w źródłach kościelnych terminem districtus. W dotychczasowej literaturze różnie interpretowano ów termin: jako „wołość” - jednostkę własnościowo-administracyjno-sądowniczą o genezie ruskiej, z dopuszczalną mieszaną strukturą własności ${ }^{14}$, jako dominium, czyli kompleks dóbr z definicji jednolity własnościowo ${ }^{15}$, wreszcie jako powiat, a więc jednostkę podziału administracyjnego i sądowniczego o metryce polskiej ${ }^{16}$. Districtus występujący w przywoływanych tutaj źródłach kościelnych nie spełnia jednak żadnego z wymienionych wyżej konstytutywnych warunków: nie wszystkie bowiem centra owych „dystryktów” zlokalizowane były w ośrodkach o starej, ruskiej metryce, a zatem nie mogły być ich prostą kontynuacją; struktura własnościowa poszczególnych „dystryktów” nie była jednolita, co z kolei wyklucza utożsamienie ich $\mathrm{z}$ dominium; wreszcie, poza jednym (przeworskim), żaden districtus nie był związany ze stolicą powiatu administracyjnego czy sądowego ${ }^{17}$. W tej sytuacji należy uznać, że kościelny districtus to $\mathrm{w}$ istocie synonim okręgu dziesięcinnego, odpowiednik małopolskiego klucza (clavis).

Dziesięciny z owych okręgów zostały, jak wspomnieliśmy, przekazane kapitule etapami, w wyniku kolejnych nadań biskupich i stanowiły, obok nieruchomości, najistotniejszy ekonomicznie składnik majątku wspólnego kapituły. Proces ten otwarty został w 1384 r. przekazaniem kapitule przez biskupa Eryka z Winsen dziesięcin biskupich z okręgu łańcuckiego ${ }^{18}$. Przed 1390 r. tenże biskup dodał do nich

${ }^{14}$ M.in. A. F a s t n a c h t, Osadnictwo ziemi sanockiej w latach 1340-1650, Wrocław 1962 , s. 32-33; A. J a n e c z e k, Osadnictwo pogranicza polsko-ruskiego. Województwo bełskie od schyłku XIV do początku XVII wieku, Warszawa 1993, s. 24; J. K u rty k a, Osadnictwo, s. 121-122, 144. Dyskusję na ten temat podsumował wraz z zestawieniem dotychczasowej literatury J. S z y s zka, Kształtowanie się podziałów terytorialnych Rusi Czerwonej na przykładzie ziemi lwowskiej, Średniowiecze Polskie i Powszechne 3 (7), 2011, s. 120-140. W odniesieniu do diecezji przemyskiej G. K l e b o w i c z, Organizacja, s. 84, podniósł problem niejednoznaczności tego terminu.

${ }_{15}$ Ostatnio T. M. Trajdos, Miechowici na ziemi przemyskiej za panowania Władysława II Jagiełły, Folia Historica Cracoviensia, 4-5, 1997-1998, s. 72.

${ }^{16}$ Ostatnio T. M. Tr a j d o s, Kapituła, s. 393.

17 Potwierdzeniem takiej hipotezy jest chociażby użycie terminu districtus w odniesieniu do prywatnego miasteczka Pruchnika (districtus Prochnicensis), które zostało lokowane dopiero w początkach XV w. i nigdy nie stanowiło centrum administracji państwowej, sądowej ani skarbowej. W skład okręgu pruchnickiego wchodziły wsie nigdy niezwiązane własnościowo z kompleksem pruchnickim (Archiwum Archidiecezji Przemyskiej [dalej cyt.: AAP], nr I, Liber conclusionum, k. 7v). Znamienne jest i to, że termin ten w odniesieniu do Pruchnika nie pojawił się ani razu w średniowiecznym materiale aktowym, z którego korzystał P. D ą b k o w s ki, Podział administracyjny województwa ruskiego i bełzkiego w XV wieku, Lwów 1939. Z kolei districtus jarosławski, obejmował w świetle rejestru dziesięcin kapitulnych z 1424 r. więcej osad niż właściwe dominium jarosławskie, znane z królewskiego nadania z $1387 \mathrm{r}$. dla Jana z Tarnowa, a ich powstanie nie jest też związane z inicjatywą dziedziców Jarosławszczyzny (np. Nowosielce, Rozbórz Stary, Uherce, czyli późniejszy Pruchnik). Z kolei okręg łańcucki znany z wykazu z 1424 r. pokrywa się z właściwym dominium łańcuckim, pierwotnie jednak niejednolitym własnościowo (D. K a r c z e w s ki, Uwagi o początkach osadnictwa klucza łańcuckiego [druga połowa XIV wieku], w: Narodziny Rzeczypospolitej. Studia z dziejów średniowiecza i czasów wczesnonowożytnych, Kraków 2012, t. II, s. 583-594).

${ }_{18}$ Nadanie to zatwierdzone zostało przez legata papieskiego Dymitra 5 V 1384 r. (AGZ VIII, nr 14; W. A b r a h a m, Powstanie, s. 326). 
dziesięciny z okręgu rzeszowskiego. W wydanych w tym samym roku statutach, określających prawa i obowiązki kapituły, wymienił bowiem w składzie jej uposażenia dziesięciny stołu biskupiego z istniejących i mogących w przyszłości powstać wsi w okręgach łańcuckim i rzeszowskim (decimas presentes et futuras cunctarum villarum in districtibus Lanchudensi et Rischowiensi) ${ }^{19}$. Były to najbogatsze okręgi w diecezji, a to z powodu dużej liczby nowo lokowanych wsi, zamieszkałych przez ludność katolicką ${ }^{20}$. Trzy lata później kolejny biskup Maciej w zamian za karczmę w Radymnie, nadaną przez swego poprzednika, przekazał kapitule dziesięciny biskupie (decimas omnes episcopales) z okręgu jarosławskiego, tj. z wszelkich ról należących do zamku i z miasta Jarosławia, z Przeworska, Nowosielec i Ostrowa, bez względu na to, w czyich są rękach, szlachty, wójtów, sołtysów czy kmieci²1. W przypadku Jarosławia i Przeworska chodziło oczywiście nie o same miasta i ich rolnicze przedmieścia, ale przede wszystkim o okoliczne wsie ${ }^{22}$. Nadanie dziesięcin z Przeworska było zresztą odpowiedzią biskupa Macieja na przekazanie trzy miesiące wcześniej dziesięciny z dóbr przeworskich (de ipsa hereditate sive opido Przeworsko - - et de villis locatis vel de novo locandis - - que infra limites hereditatis Przeworsko comprehenduntur) kościołowi parafialnemu w Przeworsku przez roszczącego sobie do nich prawa biskupa lubuskiego Jana ${ }^{23}$. Najpewniej w skład okręgu jarosławskiego wchodziły wówczas także osady, wyodrębnione później w osobny okręg

${ }^{19}$ AGZ VIII, nr 20 (10 I 1390); W. A b r a h a m, Powstanie, s. 327-329; G. K l e b o w i c z, Organizacja, s. 94-95. Natomiast T. M. Traj d o s, Kapituła, s. 393, nieprecyzyjnie podaje, że dziesięciny z okręgu rzeszowskiego przysługiwały kapitule od $1390 \mathrm{r}$.

${ }^{20}$ W 1424 r. okręg łańcucki dostarczał kapitule ponad 83 grzywny, a rzeszowski ponad 32 grzywny (AAP, nr I, k. 4v-5, 6-6v). J. K u r t y k a, Osadnictwo, s. 144, podaje, że w świetle dokumentu datowanego ogólnie na lata 1387-1416 podatki królewskie z włości rzeszowskiej miały wartość 250 kłód zboża, podczas gdy dochody z dóbr przemyskich, jarosławskich i łańcuckich wynosiły łącznie zaledwie 100 kłód.

${ }^{21}$ AGZ VIII, nr 22 (17 VII 1393). Nieprecyzyjnie oddał zakres tego nadania T. Ś 1 i w a, Kolegium, s. 32, pisząc, że były to dziesięciny pieniężne ,z okręgu jarosławskiego: Nowosielec i Ostrowa". Z kolei T. M. Tr a j d o s, Miechowici, s. 72, dokonał niefortunnego utożsamienia użytego w źródle terminu districtus z „państwem” jarosławskim, choć niewątpliwie chodzi o okręg dziesięcinny.

${ }^{22}$ Nie sposób zgodzić się ze stwierdzeniem T. M. Traj d o s a, Kapituła, s. 393, że kapituła otrzymała wówczas dziesięciny tylko „z części przeworskiego” okręgu, chyba że autor miał na myśli wsie ruskie, czasowo nieobjęte tym świadczeniem. Porównując zakres owego nadania z rejestrem wsi płacących biskupczyznę z tego okręgu z 1424 r. (AAP, nr I, k. 9-9v) oraz aktami opisywanego tu procesu, widać stały wzrost liczebny osad obciążonych tym świadczeniem, a zatem intencją biskupów było uposażenie kapituły wszystkimi aktualnie pobieranymi z danego okręgu dziesięcinami oraz mogącymi płynąć z niego w przyszłości.

${ }^{23}$ Zbiór dokumentów małopolskich, wyd. I. Sułkowska-Kuraś, S. Kuraś, t. I-VIII, Wrocław 1962-1975, tu t. IV, nr 1105 (28 IV 1393); T. M. Tr a j d o s, Miechowici, s. 71-73; G. K l e b o w i c z, Organizacja, s. 283. W 1394 r. biskup Maciej na prośbę wojewody sandomierskiego Jana z Tarnowa przywrócił temu kościołowi jedynie dziesięcinę z samego miasta Przeworska z przedmieściem i wsi Studziona (Zbiór dokumentów małopolskich, t. IV, nr 1113). Stąd też Przeworsk i Studziona nie występują w spisie dziesięcin biskupich okręgu przeworskiego z 1424 r. (AAP, nr I, k. 10). Trudno zatem stwierdzić, z jakiego powodu w wizytacji biskupa Sierakowskiego z 1745 r. wśród dziesięcin biskupich oddawanych przez parafię przeworską znalazły się także episcopalia z miasta Przeworska (AAP, 167, k. 172). 
pruchnicki ${ }^{24}$. W latach 1424 i 1430 powiększyły majątek kapitulny dziesięciny (decimas ad mensam episcopalem iure diocesiano spectantes) z okręgu tyczyńskiego ${ }^{25}$. Jako ostatnie przypadły w 1444 r. kapitule, a konkretnie jej kustoszom, dziesięciny z okręgu leżajskiego ${ }^{26}$. Inne nadania i darowizny na rzecz kapituły dotyczyły już tylko świadczeń z pojedynczych majątków, nie zaś całych okręgów ${ }^{27}$.

Sprawa charakteru i wymiaru obciążeń dziesięcinnych na rzecz biskupów przemyskich była przyczyną poważnych nieporozumień z miejscową szlachtą już w końcu XIV w., za czasów pontyfikatu biskupa Macieja ${ }^{28}$. Odmawiała ona bowiem oddawania dziesięcin w naturze, powołując się na wspomniany wyżej przywilej Kazimierza Wielkiego zwalniający mieszkańców ziem ruskich z dziesięciny snopowej w zamian za ryczałtową płatność $\mathrm{z}$ łanu ${ }^{29}$. Tymczasem, jak to zapisano w dokumencie Jagiełły z 1395 r., biskup Maciej w bulli (niewątpliwie prekonizacyjnej) otrzymał od papieża prawo poboru właśnie dziesięcin snopowych (uti litteris papalibus super decima

${ }^{24}$ Dokument nadania dziesięcin $\mathrm{z}$ okręgu pruchnickiego nie jest znany. Nie posiadała go także kapituła, skoro nie figuruje w sporządzonym w początkach XV w. spisie dokumentów przechowywanych w archiwum kapitulnym (AAP, nr I, k. 13). Być może więc w ogóle go nie było, podobnie jak nie istnieje osobny dokument nadania dziesięcin z okręgu przeworskiego. Dziesięciny te zostały bowiem nadane w 1393 r. w ramach okręgu jarosławskiego (AGZ VIII, nr 22). Ten zaś niedługo potem (ale przed 1424 r.) został, zapewne ze względów praktycznych, podzielony na mniejsze jednostki. W ten sposób wyłonić się musiały okręgi przeworski i pruchnicki (AAP, nr I, k. 9). Przekonuje o tym fakt dwukrotnego, pomyłkowego wymienienia we wspomnianych rejestrach z 1424 r. tej samej wsi Mirocin, raz w okręgu jarosławskim, a raz w przeworskim. Jest zatem wielce prawdopodobne, że i obszar późniejszego okręgu pruchnickiego pierwotnie zaliczał się do jarosławskiego, a zatem dziesięciny te zostały objęte nadaniem dla kapituły z 1393 r. Po raz pierwszy okręg pruchnicki został wymieniony w dokumencie biskupa Janusza z 2 IV 1424 r., z informacją, że pochodzące z niego dziesięciny zostały razem z innymi z okręgów rzeszowskiego, łańcuckiego, przeworskiego i jarosławskiego nadane kapitule przez jego poprzedników Eryka i Macieja (AGZ VIII, nr 47). Pośrednim dowodem na późne wyodrębnienie się okręgu pruchnickiego jest także fakt, że centra wszystkich okręgów dziesięcinnych znajdowały się w miastach. Zatem okręg pruchnicki mógł wydzielić się z jarosławskiego dopiero po powstaniu miasteczka Pruchnik, stanowiącego centrum gospodarcze, religijne i administracyjne dla okolicy. Stało się to zaś najpewniej w pierwszych latach XV w. (M. Wo ls k i, Dzieje miasta i okolic do końca XVI wieku, w: Pruchnik. Studia z dziejów miasta i okolic, wyd. 2, Kraków 2017, s. 72-73).

${ }^{25}$ AGZ VIII, nr47 (2 IV 1424), 54(22 IV 1430). W 1424 biskup nadał kapitule jedynie 24 grzywny z dziesięcin z okręgu tyczyńskiego, w 1430 r. zaś - całość tego świadczenia z okręgu, z dodatkiem dziesięcin z Rokietnicy i Błażowej. Nadanie to poprzedziła zgoda papieska z 18 I 1428 r. (Bullarium Poloniae, wyd. I. Sułkowska-Kuraś, S. Kuraś, t. I-VII, Romae-Lublini 1982-2006, tu t. IV, nr 2080). W 1466 r. okręg tyczyński przynosił kapitule 52 grzywny i 10 denarów (AAP, nr I, k. 37). Nie posiadamy niestety wykazu wsi objętych tym świadczeniem, gdyż zachowane wykazy powstały przed nadaniem.

26 AGZ VIII, nr 74 (26 VI 1444). Kustodia otrzymała wówczas też dziesięciny z Ujkowic i Stojanic w okręgu mościckim. Nieprecyzyjnie podaje zakres tego nadania G. K l e b o w i c z, Organizacja, s. 95.

${ }_{27}$ M.in. dziesięciny z Przemyśla i pięciu wsi z tego okręgu (AGZ VIII, nr 34; T. M. Tr a j d o s, Kapituła, s. 393).

${ }^{28}$ O walce biskupa o dziesięciny wspomina A. S t r z e l e c k a, Maciej (zm. 1420), kanclerz królowej, biskup przemyski, w: Polski słownik biograficzny, t. XIX (1974), s. 9.

${ }^{29}$ AGZ VIII, nr XXVI (8 VI 1397). 
manipulari sibi danda) ${ }^{30}$, co było zgodne z polityką Kościoła, ale stało w sprzeczności z długim już zwyczajem panującym na Rusi. W 1395 r. za pośrednictwem króla Władysława Jagiełły doszło najpewniej do próby ugody (compositio) między biskupem a mieszkańcami diecezji wyznania katolickiego. Król zatwierdził ją wspomnianym dokumentem wystawionym w Przemyślu 7 III 1395 r. ${ }^{31}$ Intencją władcy, inspiratora tego porozumienia (nobis complacere et nostre voluntati obtemperare desiderans), było polepszenie stanu ziem ruskich (propter meliorem et celeriorem locacionem terre nostre Russie). Była to kontynuacja Kazimierzowskiej polityki ulg wobec katolickich osadników ${ }^{32}$. Biskup, odstąpiwszy od prawa poboru dziesięcin snopowych, zgodził się na ekwiwalent pieniężny przy jednoczesnym zniesieniu najniższej stawki 4 groszy. Odtąd z płacących tyle łanów dawać miano 6 groszy, tam natomiast, gdzie dotąd płacono po 8 i 12 groszy, stawkę tę utrzymano.

Choć dokument ten stał się następnie podstawą roszczeń dziesięcinnych kapituły i biskupów wobec szlachty, w tym i omawianego tutaj procesu, to jednak konflikt nie został chyba wówczas ostatecznie zażegnany. Przed czerwcem 1397 r. biskup zwrócił się bowiem do Stolicy Apostolskiej z prośbą o pomoc, skarżąc się, że choć w sąsiednich diecezjach płacone są pełnowartościowe dziesięciny ze zbóż i bydła (licet in partibus eius civitatis et diocesis Primisliensis circumvicinis de frugibus excrescentibus et animalibus depascendibus in eisdem partibus vere decime persolvantur), to $\mathrm{w}$ jego diecezji niskie świadczenia ustalone niegdyś przez Kazimierza Wielkiego przynoszą kościołowi przemyskiemu wielką szkodę, a 4 grosze płacone z większości łanów nie stanowią nawet dwudziestej części realnej wartości dziesięciny. W konsekwencji Bonifacy IX polecił biskupowi wrocławskiemu zbadać i rozstrzygnąć tę sprawę ${ }^{33}$. Wydaje się, że spór został ostatecznie zakończony dopiero w 1406 r., kiedy biskup Maciej wystawił dokument potwierdzający zwyczaj obowiązujący na Rusi, zarówno w diecezji przemyskiej, jak i archidiecezji halickiej, pobierania przez biskupów dziesięciny w pieniądzu, a nie w naturze (in nostra et Haliciensi dioecibus - - nunc esse et ab eo tempore fuisse - - in decimis recipiendis et tollendis conswetudinem inconcusse, laudabiliter et pacifice observatam, quod in partibus Russie - - locorum ordinarii pro decimis de agris civitatum, opidorum et villarum provenientibus certam summam pecunie et non manipularem decimam recipiunt ${ }^{34}$.

Mimo wspomnianych wyżej hojnych nadań kapituła przemyska stale odczuwała niedobór środków niezbędnych do prawidłowego funkcjonowania, zwłaszcza że już w XV w. występowały trudności ze ściągalnością opłat dziesięcinnych ${ }^{35}$. Niemniej

${ }^{30}$ AGZ VIII, nr 24, wydanie według oryginału znajdującego się w AAP, I 11; Warszawa, Archiwum Główne Akt Dawnych (dalej cyt.: AGAD), Metryka Koronna 23, s. 246-247 (transumpt Zygmunta I z 1508 r.).

31 AGZ VIII, nr 24. Na temat tego dokumentu i przebiegu całego sporu przygotowuję osobną rozprawę.

${ }^{32}$ H. P a s zk i e wi c z, Polityka ruska, s. 255.

${ }^{33}$ AGZ VIII, nr 26; Bullarium Poloniae, t. III, nr 495.

${ }^{34}$ AGZ IV, nr 12 (7 V 1406); W. A b r a h a m, Powstanie, s. 322.

35 Przykładowo: w 1464 r. nie otrzymano dziesięcin z Lubaczowa, Łukowej, Felsztyna, Manczlawówki, Leksówki, Bystrowic, Kisielowa, Tuliczowa, Węgierki, Duńkowic i Ciemiężowic (AAP, nr I, k. 35v). 
w ciągu całego XV w. nie odnajdujemy śladu sporów kapituły ze szlachtą o to świadczenie. Dopiero w początkach następnego stulecia pojawiły się symptomy zbliżającego się konfliktu, a następnie dość masowy sprzeciw szlachty względem uiszczania należnych opłat. Złożyło się na to kilka czynników. Intensywny rozwój gospodarki folwarcznej spowodował konieczność powiększania areału upraw przez przyłączanie gruntów kmiecych, przymiarków oraz nowizn, uzyskiwanych z karczunku zarośli i lasów. Z wszystkich tak pozyskanych gruntów szlachta nie poczuwała się do obowiązku uiszczania dziesięcin. Był to zresztą problem ogólnokrajowy. Zjawiskiem charakterystycznym dla południowo-wschodnich ziem Korony było natomiast osadzanie Rusinów na gruntach uprawianych dawniej przez katolików, co znowu stawało się argumentem przeciw ponoszeniu powinności na rzecz Kościoła katolickiego. Na te przyczyny nałożyła się w drugiej połowie XVI w. reformacja, zyskująca wśród szlachty przemyskiej wielu zwolenników ${ }^{36}$. Biskupi przemyscy i kapituła katedralna, dostrzegając narastający problem, zaczęli już od początku XVI w. podejmować różne działania zabezpieczające swój interes, zwłaszcza przez potwierdzanie przez kolejnych władców dawnych przywilejów, wypracowywanie procedur mających dyscyplinować opornych, a nawet podniesienie pensji dla prokuratorów kapitulnych w celu zwiększenia ich motywacji do ściągania należności. Właśnie w kontekście tych dążeń należy postrzegać dwukrotne w ciągu zaledwie trzech lat (1508 i 1511) prośby o transumowanie przez Zygmunta I dokumentu Władysława Jagiełły z 1395 r. $^{37}$ W 1519 r. synod diecezjalny przemyski zajął się problemem nieoddawania mesznego przez prawosławnych osadzonych na gruntach niegdyś uprawianych przez katolików ${ }^{38}$. Problem ten nie został najwidoczniej wówczas rozwiązany, skoro w 1540 r. kapituła wystarała się u króla o ogólne potwierdzenie swoich przywilejów, w tym dawnego prawa do pobierania w pieniądzu dziesięciny biskupiej zarówno z gruntów uprawianych przez katolików, jak i Rusinów osadzonych lub mogących być w przyszłości osadzanych na gruntach zajmowanych wcześniej przez katolików ${ }^{39}$.

36 Jedyne większe studium na temat reformacji w diecezji przemyskiej dał T. Śliw a, Rozwój protestanckiej reformacji w diecezji przemyskiej w połowie XVI wieku, Kronika Diecezji Przemyskiej 1974-1977, s. 1-57. Wnioski o stosunkowo małym zasięgu protestantyzmu wśród miejscowej szlachty, zbudowane na podstawie dość jednostronnej, prawie wyłącznie kościelnej proweniencji podstawie źródłowej, nie odpowiadają stanowi faktycznemu. Materiał aktowy z ksiąg grodzkich i ziemskich dostarcza bowiem wielu nowych, nieznanych T. Śliwie, informacji o przejętych przez protestantów kościołach i różnych sporach z Kościołem katolickim. Przygotowuję na ten temat osobną publikację.

37 AGAD, Metryka Koronna 23, s. 246-247 (2 III 1508); tamże 26, k. 79v-80 (11 II 1511). Oryginał dokumentu Jagiełłowego nie figuruje w spisie archiwum kapituły z początku XV w. (AAP, nr I, k. 13). Być może jednak został on zdeponowany w archiwum biskupim, jako że jego postanowienia dotyczyły przede wszystkim powinności na rzecz biskupów. Nie bez przyczyny w 1508 o jego zatwierdzenie wystąpił do króla właśnie biskup wraz z kapitułą, a w 1511 r. sam biskup.

${ }^{38}$ Analecta ad historiam iuris canonici in diocesi Premisliensi, wyd. B. Ulanowski, Archiwum Komisji Historycznej Akademii Umiejętności, t. V (Scriptores rerum Polonicarum, t. XIII), Kraków 1889, s. 382-383.

${ }^{39}$ AAP, 143, k. 62v-64; S. Nakielski, Miechovia sive promptuarium antiquitatum monasterii Miechoviensis, Cracoviae 1634-1646, s. 628-629 (18 III 1540): Praeterea, quia certo edocti sumus praefatos venerabiles prelatos, canonicos totumque capitulum ecclesiae cathedralis 
Innym, wspomnianym już wyżej, problemem było odmawianie przez szlachtę świadczeń dziesięcinnych z nowizn przyłączonych do folwarków. Niejednokrotnie zresztą dziesięciny te były przejmowane przez miejscowych plebanów ${ }^{40}$. W $1548 \mathrm{r}$. kapituła podjęła decyzję o zwróceniu się do biskupa, aby zbadał tę kwestię i dziesięciny te włączył do dóbr stołu biskupiego ${ }^{41}$. Nic jednak w tej materii nie udało się najwidoczniej zdziałać, skoro sprawa ta powracała jako nierozwiązana również w następnych latach ${ }^{42}$.

W 1552 r. kapituła po raz kolejny wysłała na sejm swego przedstawiciela (dziekana Pawła Tarłę) z przywilejami w celu ich potwierdzenia. Były wśród nich m.in. transumpt z 1508 r. dokumentu Jagiełłowego (confirmationis Sigismundi regis super redditione decimarum mense capitulari per octo [!] grossos Bohemicales) oraz wspomniany wyżej dokument z 1540 r. potwierdzający ogólnie prawa kapituły (privilegium super solutione episcopalium et missalium de agris etiam Rutenicis Sigismundi regis $)^{43}$. Zostały one (wraz z trzema innymi) zatwierdzone na sejmie w Piotrkowie 27 II $1552 \mathrm{r}^{44}$

Na kapitule 1554 r. zebrani, utyskując na coraz większe trudności w ściągalności dziesięcin, ustalili w porozumieniu z biskupem sposób postępowania wobec opornych. Prokurator kapituły miał do nich kierować list z żądaniem wyegzekwowania należności od swoich poddanych, a w razie dalszego oporu miało być do nich wystosowane ostrzeżenie przez oficjała lub kapitułę ${ }^{45}$. W 1563 r. kapituła podjęła decyzję

Praemisliensis esse ab antiquo in possesione et perceptione episcopalium biskupczyzna dictorum, peccunia solvi solitorum -- iuxta consuetudinem veterem ipsis prelatis et canonicis capituloque--tam per catholicos - - quam etiam per Ruthenos in agris, quae prius catholicorum fuerant, locatos et in futurum locandos esse solvenda et sine tergiversatione aliqua extradenda.

${ }^{40}$ Rozróżniano w praktyce nowizny powstałe z sukcesywnego powiększania istniejących ról o wykarczowane sąsiednie tereny, z których dziesięcinę mieli pobierać miejscowi plebani, oraz nowo lokowane wsie na wykarczowanych terenach, z których świadczenie to miało przysługiwać biskupom (S. C h [ o d y ń s k i], Dziesięcina w Polsce, s. 483).

${ }^{41} \mathrm{AAP}, \mathrm{nr}$ II [Liber conclusionum], k. 63v: quoniam per nobiles istius diocesis propter amplianda praedia multi agri ex nova radice extirpantur, ex quibus decimas manipulares ipsi nobiles pro libito suo vel dispensant vel retinent iniuste, aliqui etiam ecclesiarum rectores eas apropriant suis ecclesiis. Ideo domini capitulares concluserunt reverendissimum dominum episcopum rogare, ut de huiusmodi decimis ac agris noviter eradicatis excrescentias inquirere faciat et decimas ipsas, quoniam pro episcopali mensa de iure communi debentur, pro augenda mensa sua applicet.

${ }^{42}$ AAP, nr II, k. 130: praefati domini capitulariter congregati in diversis capitanealibus pro excrescenciis alias decimis novalibus per diversos nobiles diocesis huius contra iura nulliter et de facto usurpatis et retentis reverendissimum dominum episcopum Praemisliensem rogandum et impense exoptandum decreverunt.

${ }^{43}$ AAP, nr II, k. 86.

${ }_{44}$ AGAD, Metryka Koronna 80, k. 153-153v, 155; Matricularum Regni Poloniae summaria, t. V, wyd. T. Wierzbowski, Warszawa 1919, nr 1127.

45 AAP, nr II, k. 97: attendendo, quod quanto ulterius, tanto deterius, decimae peccuniariae mense capitulari diminuntur et non solvuntur multorum nobilium pernicatia, qui hominibus suis prohibent ne huiusmodi decimam peccuniariam solverent. Unde supradicti domini integritati mense capitulari providendo sequuti consilium reverendissimi domini episcopi decreverunt, ut dominus procurator capituli pro tempore existens primo dominos haereditarios villarum, ex quibus peccuniarie decime retinentur vel non solvuntur, litteris suis petat et requirat, ut 
o podwyższeniu wynagrodzenia dla prokuratora, aby sprawniej ściągał dziesięcinę biskupią ${ }^{46}$. Również podczas zimowej kapituły w 1567 r. skierowano prośbę do biskupa, aby zwrócił się do szlachty z przypomnieniem obowiązku płacenia kapitule dziesięcin $\mathrm{z}$ gruntów chłopskich zajętych na folwarki ${ }^{47}$.

W 1569 r. w uchwale kapituły pojawił się wątek dotyczący konwersji szlachty na protestantyzm i związanego z tym wstrzymywania dotychczasowych świadczeń na rzecz kapituły ${ }^{48}$. Nie była to zresztą jakaś lokalna przemyska specyfika. W drugiej połowie lat siedemdziesiątych XVI w. konflikt między szlachtą a duchowieństwem na tle egzekucji zaległych dziesięcin i jurysdykcji w tych sprawach ogarnął cały kraj na taką skalę, że postanowiono sprawę uregulować specjalnym aktem prawnym, tzw. kompozycją. Niestety kolejne sejmy począwszy od $1578 \mathrm{r}$. odkładały tę kwestię i nie podjęły żadnych systemowych decyzji ${ }^{49}$.

de subditis suis iustitiam faciant et subditos suos ad solutionem decimarum pro officio suo compellant, alioquin si id rogati facere neglexerint, extunc litteris monitionis domini officialis seu capituli movendi erunt.

46 Tamże, k. 98: In eodem capitulo supramemorati domini capitulares attendentes magnas difficultates et damna propter retentionem procesuum per plebanos subinde fieri solitam, in exigendis decimis episcopalibus evenire, tali itaque obviantes incommodo, unanimis voluntatibus sexagenam unam peccuniarum procuratori suo capitulari ad marcas decem eidem antiquitus dari solitas, propter cursores ea in re mittendos et pro labore huiusmodi contentandos superaddiderunt dandamque decreverunt, quo eo facilius episcopalia et alii redditus capitulares exigi et colligi integre possint.

47 Tamże, k. 154v: Quoniam propter ademptionem agrorum ad solutionem episcopalium adstrinctorum ac ad agros praediales per multos nobiles in hac diocesi adiunctorum (qui ex huiusmodi agris cmethonalibus prediis suis applicatis et adiunctis nec spiritualia debita, neque decimas manipulares ecclesiis solvuunt) ecclesia cathedralis Praemisliensis damnum plurimum sustinet, rogandum reverendissimum dominum episcopum venerabile capitulum decrevit, ut apud nobiles sua reverendissima paternitas intermissionem solutionis episcopalium ac item decimarum manipularium ecclesiis parochialibus factam per litteras suas ac omni suo studio removere dignetur.

${ }^{48}$ Tamże, k. 164-164v (1 I 1569): considerando factam iam magnam proventuum capitularium diminutionem idque propter agrorum per catholicos antea cultorum, ex quibus decimae peccuniales mensae capitulari antiquitus solvebantur, per multos nobiles ab ecclesia sancta catholica in haeresim lapsos ademptionem. Choć początki reformacji na Rusi sięgają lat pięćdziesiątych XVI w., dopiero w 1570 r. w aktach synodalnych odnajdujemy superintendenta dystryktu ruskiego, czyli przemyskiego (Akta synodów różnowierczych w Polsce, t. II-III, opr. M. Sipayłło, Warszawa 1972-1983, tu t. II, s. 271).

49 Sejm w 1578 r. odłożył tę kwestię do sejmu następnego, przekazując, mimo protestu duchowieństwa, sprawy o dziesięciny do kompetencji Trybunału Koronnego. Podobnie stało się na sejmie 1581 r., kiedy to spór o egzekucję wyroków trybunalskich w sprawach o dziesięciny odesłano znowu do mającej nastąpić kompozycji (Volumina constitutionum, t. II, cz. 1, opr. S. Grodziski, I. Dwornicka, W. Uruszczak, Warszawa 2005, s. 408, 451; S. C h [ o d y ń s k i], Dziesięcina w Polsce, s. 485-486, 488). Sejm koronacyjny w 1588 r. znowu nie przyniósł porozumienia, a załatwienie spraw dziesięcinnych pomieszczono w recesach: „A iż też do kompozycyi należy differentia o dziesięcinach, tedy też one z postępkami prawnemi wszelakiemi, do tego czasu zawieszone być mają" (Volumina constitutionum, t. II, cz. 2, opr. S. Grodziski, Warszawa 2008, s. 87). Sprawa kompozycji była poruszana jeszcze na sejmie w 1607 r. (tamże, s. 343). Uregulowało ją dopiero breve Urbana VIII Cum sicut dilectus z 27 XI 1634 r., zezwalające biskupom na zamianę dziesięciny snopowej na pieniężną na drodze ugody między stronami (S. C h [ o d y ń s k i], Dziesięcina w Polsce, s. 486). 
Właśnie na lata siedemdziesiąte XVI w. przypadają w diecezji przemyskiej pierwsze uchwytne źródłowo zatrzymania biskupczyzny, a także coraz liczniejsze przejęcia kościołów przez protestantów ${ }^{50}$. W 1578 r. na prośbę protestanckiej szlachty ziemi przemyskiej synod generalny obradujący w Piotrkowie wyznaczył nowego superintendenta dystryktu ruskiego ${ }^{51}$. Spowodowało to wzmocnienie struktur Kościoła protestanckiego na Rusi, z czym w parze przyszło znaczne nasilenie się na początku lat osiemdziesiątych działań wrogich wobec Kościoła katolickiego. W tym kontekście dziwi zatem zupełny brak śladów reakcji kapituły na zaistniałą sytuację. Dopiero bowiem w styczniu 1587 r. zajęła się ona problemem wstrzymanych dziesięcin, kiedy prokurator, kanonik Feliks de Valle, informując o trudnościach w zbieraniu dziesięcin z łanów przejętych przez prawosławnych, prosił o wypracowanie jakiegoś sposobu postępowania w takich przypadkach ${ }^{52}$. Na kapitule 24 VI 1589 r. kanonicy, stwierdzając znowu znaczne zmniejszenie dochodów z powodu nieuiszczania dziesięcin, uznali za konieczne zaostrzyć obowiązek rezydencji kanoników, grożąc niewypłacaniem diet dla nieobecnych ${ }^{53}$. Nerwowość kapituły powiększały także stale rosnące koszta prac budowlanych przy katedrze oraz spór z biskupem o podział obciążeń z tego tytułu.

Jesienią 1589 r. odbył się w Piotrkowie synod prowincjonalny, na którym dyskutowano m.in. sposób przywrócenia Kościołowi zaległych dziesięcin i jurysdykcji duchownej w tych kwestiach. Jak pisał prymas Stanisław Karnkowski: „Należy radzić nad sposobem przywrócenia Kościołowi w Polsce dziesięcin i określić rodzaj sądu do rozstrzygania spraw o dziesięciny, i o zniesienie, i wykreślenie raz na zawsze wyrazu o kompozycji, czyli układu w tych sprawach ze stanem świeckim; zwrócić się należy do króla i senatu z żądaniem, aby należne duchownym dziesięciny, dotąd nie wypłacane, zostały im oddane, teraz, po zerwaniu w tej sprawie przez stan świecki układów o kompozycję, przeciwko czemu protestował uroczyście cały stan duchowny"54. Kontrowersje wokół ostatecznego kształtu uchwał synodalnych spowodowały znaczne opóźnienie w ich wprowadzeniu w życie. Dopiero na początku lat dziewięćdziesiątych Kościół zaczął występować na drogę sądową przeciw szlachcie

${ }^{50}$ W 1573 wstrzymano płatność z Pełkiń, a w 1578 r. ze Zwięczycy, Cieszacinka i Ożeńska (Przeworsk Z. 36 s. 403-404, 632, 645-646).

${ }^{51}$ Został nim mianowany na synodzie w Piotrkowie w czerwcu 1578 r. zasłużony pastor Wojciech Biskup (Episcopus): Clarissimi viri, qui sunt in vicinio Praemisliae, petierunt per suas litteras ad instaurandum et conservandum ordinem ecclesiae Christi sibi et vicinioribus submontanis ecclesiis in superintendentem constitui auctoritate generalis synodi Albertum Episcopum, pastorem in Cracovia (Akta synodów, t. III, s. 38).

52 AAP, $\mathrm{nr}$ II, k. 209: decimarum peccunialium, quae episcopalia vocantur, diffcilem admodum esse exactionem accusavit, quae per Ruthenos agros catholicorum, ex quibus huiusmodi episcopalia semper solvebantur, possidendos solvi negantur et propterea multum proventuum ecclesiae huius diminutum esse, quesivitque modum sibi dari et in futurum super dictarum decimarum fienda exactione provideri.

${ }_{53}$ AAP, nr II, k. 213: proventuum capitularium in decimis peccunialibus antiquitus ex agris tam oppidorum, quam etiam villarum huius diocesis ad mensam capituli exsolvi solitorum et iuxta contenta privilegii desuper confecti debitorum, propter non solutionem ipsarum decimarum magnam esse diminutionem videntes.

${ }^{54}$ M. M o r a w s k i, Synod piotrkowski w roku 1589, Włocławek 1937, s. 33, 49-50. 
wstrzymującej świadczenia kościelne ${ }^{55}$. We wrześniu 1590 r. także i kapituła przemyska zwróciła się do właścicieli majątków, z których przestały płynąć dziesięciny, z żądaniem uregulowania zaległości. Najwięcej pozwów, gdyż aż dziewięć, dotyczyło majątków leżących w okręgu pruchnickim, po sześć w jarosławskim i rzeszowskim, po dwa w przeworskim i tyczyńskim oraz jeden w łańcuckim. Zastosowano przy tym być może procedurę przyjętą przez kapitułę już w $1554 \mathrm{r}^{56}$

Jako moment zaprzestania uiszczania tego świadczenia we wszystkich bez mała pozwach wskazano $1583 \mathrm{r}^{57}$ Trudno stwierdzić, skąd wzięła się taka właśnie data. Była najpewniej umowna, gdyż mało prawdopodobne, aby nagle, w jednym roku zaprzestało płacić dziesięcinę biskupią tak wielu właścicieli. Niewykluczone jednak, że rzeczywiście około tego roku szlachta, oczekująca od lat na decyzję w sprawie „kompozycji”, wstrzymała masowo uiszczanie świadczenia na rzecz Kościoła ${ }^{58}$. Być może cezura ta wynikała również z podjętych w tym właśnie roku działań nowego biskupa Jana Borukowskiego, zmierzających do podniesienia dyscypliny wśród duchowieństwa, ustanowienia nowych kanonii gracjalnych oraz troską o majątek kapitulny ${ }^{59}$.

Nie znamy pełnej skali wstrzymania przekazywania dziesięcin, a zatem liczby skierowanych do szlachty upomnień. Nie wiemy też, ilu adresatów odpowiedziało pozytywnie na wezwanie kapituły. Porównując pochodzący z 1424 r. wykaz wsi obciążonych tym świadczeniem w poszczególnych okręgach (obejmujący 104 osady, bez okręgu tyczyńskiego) z późniejszymi aktami procesowymi (55 osad, bez okręgu tyczyńskiego), sądzić można, że większość szlachty wywiązywała się jednak z obowiązku dziesięcinnego. Pamiętać też należy, że ów spis sprzed z górą stu lat $\mathrm{z}$ oczywistych względów nie obejmował wsi w całości zamieszkałych przez ludność ruską oraz lokowanych po dacie jego sporządzenia ${ }^{60}$. Zatem owych 55 osad to niewątpliwie znacznie mniej niż połowa wszystkich zobowiązanych do świadczenia dziesięciny biskupiej w drugiej połowie XVI w.

${ }^{55}$ W 1595 r. zebrani na synodzie protestanckim w Toruniu skarżyli się, że księża, nie czekając na kompozycję, wznowili procesy sądowe o dziesięciny (Akta synodów, t. III, s. 156).

${ }_{56}$ Sladem zastosowania tej procedury jest pismo wystosowane w 1590 r. przez kapitułę na prośbę wikariuszy katedralnych, wzywające dziedzica do uiszczenia zaległej od pięciu lat dziesięciny z folwarku w Jaskmanicach (AAP, nr II, k. 216).

57 Jedynie Krystyna z Osolina wdowa po Mateuszu Dunikowskim z Pełkiń zalegała z płatnością od 1573 (Przeworsk Z. 36 s. 645-646), Anna żona Stanisława Chociwskiego sędziego ziemskiego rawskiego i Katarzyna córka zm. Erazma Cieszackiego, żona Jana Bzowskiego dziedziczki Cieszacinka i Ożeńska - od 1578 (tamże, s. 632), a Stanisław Porudeński ze Zwieńczycy - od 1578 r. (tamże, s. 403-404).

${ }_{58}$ M. M or a w s ki, Synod, s. 33; S. C h [ o d y ń s ki ], Dziesięcina, s 488.

59 F. P a w ł o w s k i, Premislia sacra, s. 318-321. J. K w o l e k, Borukowski Jan z Bielina, w: Polski słownik biograficzny, t. II (1936), s. 354-356, nie przytacza żadnych działań wyrażających troskę biskupa o majątek kapitulny.

${ }^{60}$ Liczba osad wymienionych w pozwach z 1590, a niewystępujących w rejestrze z 1424 r., najwyższa jest w okręgu pruchnickim (7) i w jarosławskim (5). W miarę posuwania się na zachód radykalnie spada: w rzeszowskim to 3, w przeworskim to 1 i żadnej w łańcuckim. Dowodzi to z jednej strony znacznego przyrostu nowo lokowanych wsi na terenach jeszcze w początku XV w. słabiej zaludnionych, a także poważnych zmian w składzie etnicznym i konfesyjnym na tych właśnie terenach na korzyść wyznania rzymsko-katolickiego. 
W 26 przypadkach najwyraźniej upomnienie nie przyniosło skutku, skoro przeciw dziedzicom skierowany został pozew sądowy. Również i ten środek zawiódł, gdyż w pierwszym terminie, przypadającym 18 IX 1590 r., nie stawił się nikt z pozwanych. W drugim terminie: 17 IX 1591 r., mającym już status zawity, wszyscy niemal pozwani (z wyjątkiem Małgorzaty z Narajowa wdowy po Jerzym Skorucie, pani oprawnej wsi Lutoryż), stawili się bądź to osobiście (4 przypadki), bądź przez pełnomocników ${ }^{61}$. Aż w dziewięciu przypadkach funkcję pełnomocnika pełnił Florian Suchorabski herbu Ostoja, dziedzic Bóbrki, późniejszy miecznik przemyski, sam zresztą również pozwany ${ }^{62}$. Pochodził z rodziny protestanckiej, co tłumaczy jego zaangażowanie i opór w uznaniu roszczeń kapituły ${ }^{63}$. Nie wiemy nic o jego edukacji, musiał być jednak dobrze obeznany z prawem, skoro na sejmie w 1601 r. został wyznaczony do komisji mającej zająć się korekturą prawa ziemskiego ${ }^{64}$. Zapewne, aby móc reprezentować pozostałych pozwanych, uregulował w 1591 r. własne zaległości za lata 1583-1588 ${ }^{65}$. Kapitułę reprezentował we wszystkich bez mała postępowaniach kantor Adam Wawrzyniec Łojecki herbu Samson, o którym współczesny mu Bartosz Paprocki pisał: „mąż uczony, był artium et philosophiae magister promocji krakowskiej, w łasce Anny królowej" ${ }^{6}$. Na krótko przed rozpoczęciem opisywanego procesu, w czerwcu 1589 r., powrócił z Włoch, gdzie zdobył właśnie stopień doktora obojga praw i w następnych latach był jednym z najbardziej aktywnych członków kapituły ${ }^{67}$.

${ }^{61}$ Przeworsk Z. 36, s. 402, 1167-1168.

62 Żonaty był trzykrotnie, m.in. z Jadwigą Bobrownicką, córką Baltazara podstolego podlaskiego, której 30 V 1590 r. w grodzie lubelskim darował wszystkie swoje dobra i sumy zastawne w województwie ruskim (Przeworsk Z. 15, s. 415-419). Niewykluczone, że krok ten podyktowany był zaostrzającym się stosunkiem Kościoła wobec różnowierców i obawą o bezpieczeństwo dóbr. Z Jadwigą miał dzieci: Hieronima (ur. ok. 1583), Bernarda (ur. ok. 1586), Macieja (ur. ok. 1588) oraz córki Barbarę i Beatę; wszystkim im wyznaczył w 1596 r. opiekunów, synom do 24 roku życia, córkom do zamążpójścia, w osobach kasztelana sanockiego Jana i Krzysztofa Drohojowskich, Samuela Trojeckiego oraz swego stryja Piotra Suchorabskiego. Około 1596 r. ożenił się ponownie z ziemianką bełską Zofią Podhorecką, córką Piotra Duszy (Przeworsk Z. 16, s. 18-24).

${ }^{63}$ Przeworsk Z. 38, s. 784-785. Syn Floriana, Bernard (Biernat) Suchorabski z Bratkowskiej Góry, studiował od 1600 r. na uniwersytecie w Lipsku (S. To m k o w i c z, Metrica nec non liber nationis Polonorum, w: Archiwum do dziejów literatury i oświaty w Polsce, t. II, Kraków 1882, s. 438) i był zdeklarowanym protestantem (W. L o z i ń s k i, Prawem i lewem. Obyczaje na Czerwonej Rusi w pierwszej połowie XVII wieku, t. I, wyd. 6, Kraków 1960, s. 91, 118). On to zapewne był obecny na synodzie różnowierczym w Lublinie 24 VI 1623 r. (Akta synodów, t. III, s. 448).

${ }^{64}$ Volumina constitutionum, t. II, cz. 2, s. 274; K. Ni e s i e c k i, Herbarz polski, wyd. J. N. Bobrowicz, t. I-X, Lipsk 1839-1845, tu t. VIII, s. 559. W 1587 r. Florian Suchorabski posłował z województwa ruskiego na zjazd w Krakowie poprzedzający sejm koronacyjny (Volumina constitutionum, t. II, cz. 2, s. 52).

${ }^{65}$ Za kolejne dwa lata sąd zasądził mu płatność w niższej niż tego się domagała kapituła wysokości, wskazując jako podstawę kwity opłaconego podymnego: iuxta quiettationes fumalium (Przeworsk Z. 36, s. 344, 1121, 1300-1301; 37, s. 215-216).

${ }^{66}$ B. P a p r o c k i, Herby rycerstwa polskiego, wyd. K. J. Turowski, Kraków 1858, s. 706; zob. też K. N i e s i e ck i, Herbarz, t. VI, s. 263; A. B o n i e c k i, Herbarz polski, t. XV, Warszawa 1912, s. 363.

${ }^{67}$ AAP, nr II, k. 213v (24 VI 1589). Zanotowano wówczas, że Łojecki uzyskał promocję doktorską w Padwie w tamtejszym studium generale, przy czym nad słowem Pataviense dopisano później inną ręką: Romano. 
Z akt procesowych wnosić można, że pozwani w wielu wypadkach byli zaskoczeni żądaniem kapituły, gdyż świadczenie takie z ich majątków nie było już od dawna (albo i w ogóle) egzekwowane ${ }^{68}$. Zapewne w części chodziło tu o wsie stosunkowo nowe, niefigurujące $\mathrm{w}$ dawnych spisach ${ }^{69}$. Większość pozwanych żądała od kanoników wskazania podstawy prawnej roszczenia, ci zaś na kolejnym terminie (26 XI 1591) przedłożyli wspomniany już kilkakrotnie dokument Władysława Jagiełły z 1395 r. Wówczas część pozwanych podniosła zarzut, że o przywileju tym nikt dotąd nie słyszał, że jest on nieważny i bezużyteczny, wobec czego zażądała zbadania jego autentyczności ${ }^{70}$. Kanonicy wykrętnie replikowali, że nie muszą udowadniać prawdziwości dokumentu, gdyż spór toczy się jedynie o zaległe dziesięciny, a nie o samo prawo do ich pobierania: non debere super usum privilegii sui aliquam probationem facere, cum ad praesens saltim pro reliquis episcopalibus non autem pro toto actores $a_{\text {ant }}{ }^{71}$. Być może wątpliwości szlachty nie były całkiem bezzasadne, skoro brak śladów wcześniejszego powoływania się kapituły na ów dokument jako podstawę uprawnień dziesięcinnych.

W toku dalszego postępowania okazało się, że kapituła pomyłkowo skierowała trzy pozwy przeciw dziedzicom, którzy już wcześniej zapłacili należne dziesięciny $^{72}$. Kolejnych sześć spraw zakończyło się uznaniem przez pozwanych roszczeń kapituły bez wdawania się w proces i zapłaceniem zaległych dziesięcin ${ }^{73}$. W jednej sprawie, przeciw Stanisławowi Derszniakowi, kapituła okazała wyjątkową ustępliwość, rezygnując z roszczeń o należność za 5 lat, a żądając jedynie uregulowania

${ }^{68} \mathrm{~Np}$. Konstanty Korniakt z Rogóżna oraz Stanisław Porudeński ze Zwięczycy twierdzili, że z wsi tych nigdy nie płacono dziesięciny biskupiej (Przeworsk Z. 37, s. 243-247), choć figurują one w wykazie wsi objętych tym świadczeniem z 1424 r. (AAP, nr I, k. 4v, 6).

${ }^{69}$ Odpowiedź w tej kwestii przynieść może dopiero szczegółowe badanie historii poszczególnych wsi, na co nie ma tutaj miejsca. Przykładowo jednak - spośród 7 wsi w okręgu pruchnickim, wobec których kapituła zgłosiła roszczenia, a niefigurujących w rejestrze z 1424 r., aż 4 (Jodłówka, Świebodna, Kramarzówka, Węgierka) powstały niewątpliwie po tej dacie, w wyniku kolonizacji wewnętrznej (W. B la j e r, Pradzieje i wczesne średniowiecze okolic Pruchnika, w: Pruchnik. Studia z dziejów miasta i okolic, wyd. 2, Kraków 2017, s. 20-21; M. Wo 1 s k i, Dzieje miasta, s. 52-54, 62; M. W o ls k i, W. B l a j e r, Zanikłe miejscowości w okolicach Pruchnika w dawnej ziemi przemyskiej, w: Wieś zaginiona. Stan i perspektywy badań, Gliwice 2016, s. 238-240).

${ }^{70}$ Przeworsk Z. 37, s. 245 (Porudeński); zob. tamże, s. 61 (Derszniak): pretextu privilegii asserti nullius et inusitati nec unquam auditi.

${ }^{71}$ Tamże, s. 61-62 (Derszniak).

72 Byli to: dziedziczka dóbr tyczyńskich, katoliczka Anna z Pilicy żona wojewody pomorskiego Krzysztofa Kostki; córki zmarłego Erazma Cieszackiego z Cieszacinka i Ożeńska, Anna żona sędziego ziemskiego rawskiego Stanisława Chociwskiego i Katarzyna żona Jana Bzowskiego; Krzysztof i Mikołaj Łodzińscy synowie zmarłego Jana z Żuklina (Przeworsk Z. 36, s. 1010-1011, 1181-1183).

${ }^{73}$ Tak postąpili: kasztelan czechowski Mikołaj Spytek Ligęza, dziedzic dóbr rzeszowskich (tamże, s. 1222-1223); Krystyna z Osolina wdowa po Mateuszu Dunikowskim z Pełkiń (tamże, s. 1226-1227); dziedzice Krzeczowic: Anna z Jaskmanic wdowa po Eustachym Krzeczowskim, wówczas już żona Stanisława Chmieleckiego, oraz Stanisław i Gabriel Krzeczowscy, wreszcie Marcin Chwał (Przeworsk Z. 37, s. 155-156); Łukasz Orzeł posesor Lubieni (tamże, s. $217-$ 218); Stanisław i Piotr Porudeńscy, bracia zmarłego w międzyczasie pozwanego Andrzeja dziedzica połowy Cieszacina (tamże, s. 213-214). 
zaległości z 2 lat, czyli od śmierci jego matki Magdaleny z Pieniążków ${ }^{74}$. Przyczyn tej decyzji niestety nie znamy, podobnie jak przebiegu dziewięciu kolejnych spraw. Z milczenia źródeł można jednak wnosić, że i w ich wypadku strony polubownie uregulowały zaległości ${ }^{75}$. Jedynie w pozostałych siedmiu postępowaniach pozwani zakwestionowali prawo kapituły do pobierania biskupczyzny, wdając się w polemikę dotyczącą samej natury tego świadczenia. Tym samym doszło do zawiązania sporu, dzięki czemu dysponujemy dziś znakomitym źródłem, zarówno do dziejów diecezji przemyskiej w czasach reformacji, jak i do kultury prawniczej oraz wiedzy historycznej miejscowej szlachty.

W spór z kapitułą wdały się więc następujące osoby: 1) dziedziczki Jarosławszczyzny, nieletnie wówczas córki zmarłego wojewody sandomierskiego Jana Kostki - Anna, późniejsza żona wojewody wołyńskiego, kniazia Aleksandra Ostrogskiego, i Katarzyna, potem żona Adama Hieronima Sieniawskiego ${ }^{76}$; 2) Stanisław Stadnicki z Łańcuta, zwany Diabłem; 3) podstoli przemyski Jan Pieniążek, dziedzic dóbr pruchnickich $^{77}$; 4) Konstanty Korniakt z Białoboków; 5) Stanisław Porudeński ze Zwięczycy; 6) Mikołaj Giżyński z Siennowa ${ }^{78}$ i 7) Łowieccy z Łowiec.

Była to grupa niejednolita pod względem konfesyjnym, choć z przewagą protestantów. Byli nimi Pieniążek, Stadnicki, Giżyński i Porudeński. Znajdujemy tu też

${ }^{74}$ Katolik Stanisław Derszniak, wychowanek uniwersytetu w Padwie, dziedzic Czelatyc, Pantalowic, Łopuszki i Zagórza (tamże, s. 664-666; S. W i n d a k i e w i c z, Księga nacji polskiej w Padwie, w: Archiwum do dziejów literatury i oświaty w Polsce, t. VI, Kraków 1882, s. 23).

${ }^{75}$ Byli to: Katarzyna z Sienna wdowa po stolniku przemyskim Janie Biejkowskim z Pełnatycz (Przeworsk Z. 36, s. 338-339, 999-1000, 1180-1181); Dorota z Łysakowa wdowa po mieczniku przemyski Wojciechu Lutosławskim z Cieszacina (tamże, s. 339, 1183-1184, 1299-1300; Z. 37, s. 310-311); katoliczka Anna z Leszcz wdowa po Stanisławie Dydyńskim z Zarzecza i Rożniatowa (tamże, s. 340), w 1597 r. fundatorka kościoła w Zarzeczu (Przeworsk Z. 16, s. 279-290); Remigian Orzechowski z Żurowiczek Długich (Przeworsk Z. 36, s. 342 343, 1009-1010, 1090-1091); Małgorzata z Narajowa wdowa po Jerzym Skorucie z Lutoryża (tamże, s. 402, 1167-1168); Jadwiga z Łaska wdowa po chorążym czerskim Piotrze Biejkowskim z Błażowej, Hermanowej i Błędowej (tamże, s. 404, 999-1000); Marcin Morawski dziedzic części Morawska (tamże, s. 645, 1059-1060, 1304, 1338-1339; Z. 37, s. 218-220); Jan Morawski dziedzic drugiej części Morawska (Przeworsk Z. 36 s. 646, 1095-1096; Z. 37 , s. 309-310); Magdalena z Zakliczna Jordanówna wdowa po kasztelanie sandomierskim Stanisławie Sobku z Zabierzowa (Przeworsk Z. 36, s. 111-1112).

76 Anna wyszła za mąż w 1592 (J. W o 1 ff, Kniaziowie litewsko-ruscy od końca czternastego wieku, Warszawa 1895, s. 358), Katarzyna zaś w 1593 r. (M. N a g i e 1 s ki, Sieniawski Adama Hieronim, w: Polski słownik biograficzny, t. XXXVII [1996], s. 97-99).

77 Był on synem ciążącego ku protestantyzmowi sędziego ziemskiego krakowskiego Jana Pieniążka i Doroty z Próchnickich (M. W o l s k i, Reformacyjny epizod w historii Pruchnika, w: Fontes et historia. Prace dedykowane Antoniemu Gąsiorowskiemu, Poznań 2007, s. 229244). Wraz z bratem Stanisławem wpisał się w 1558 r. na protestancki uniwersytet w Bazylei (J. Kalle n b a ch, Polacy w Bazylei w XVI wieku, w: Archiwum do dziejów literatury i oświaty w Polsce, t. VI, Kraków 1890, s. 3: Pincoseck), a potem z drugim bratem Piotrem studiował w Lipsku (S. T o m k o w i c z, Metrica, s. 433, 434, 440). W 1595 r. niewątpliwie z jego inicjatywy odbył się w u niego w Pruchniku synod różnowierczy dystryktu ruskiego (Akta synodów, t. III, s. 118).

${ }^{78}$ Przeworsk Z. 36, s. 344, 1142, 1502-1505; Z. 37, s. 247-250. 
gorliwą katoliczkę Annę z Kostków Ostrogską, fundatorkę klasztoru benedyktynek w Jarosławiu, oraz zapewne prawosławnego Greka z wyspy Kandii, Konstantego Korniakta, fundatora co najmniej czterech kościołów katolickich (w Gaci, Ostrowie, Kraczkowej i Wysokiej) ${ }^{79}$. Spośród wszystkich tych osób najciekawszą postacią był niewątpliwie Jan Pieniążek, który jako jedyny występował w sądzie osobiście, formułując logiczne i mocno osadzone w realiach prawnych i historycznych racje.

Argumentacja kapituły była w swojej zasadniczej części jednolita, a opierała się na literalnej wykładni dokumentu Władysława Jagiełły z 1395 r. (nec eiusmodi verba privilegii alias interpretari possunt, nisi prout in se sonant), niedopuszczającej odmiennej interpretacji poszczególnych jego fragmentów ani też niebiorącej pod uwagę uwarunkowań historycznych ${ }^{80}$. Odwoływała się do dawności tego świadczenia, pobieranego od niepamiętnych czasów na podstawie wspomnianego przywileju (eiusmodi episcopalem vigore eiusdem privilegii et consuetudinis antiquissimae dare et solvere est astrictus) ${ }^{81}$. Podnosiła, że pozwani i ich poprzednicy (przodkowie) zawsze je uiszczali ${ }^{82}$. Wskazywała, że biskupczyzna jest świadczeniem różnym zarówno od dziesięciny snopowej z folwarków szlacheckich (nec eo sensu mixto intelligi possunt, ut decima manipularis eadem sit, quam episopalia), jak i od mesznego ${ }^{83}$. Przekonywała zatem, że także oddający dziesięcinę snopową swojemu plebanowi nie są zwolnieni od płacenia biskupczyzny ${ }^{84}$, podobnie jak fakt oddawania mesznego lub dziesięciny duchownemu protestanckiemu nie może godzić w interes kapituły ${ }^{85}$. Odpowiadając na zarzut szlachty, że domaga się dziesięciny od Rusinów, kapituła replikowała, że ugoda z czasów Jagiełły dotyczyła wszystkich bez wyjątku mieszkańców diecezji ${ }^{86}$.

Linia obrony, w większości reprezentowana, jak wspomnieliśmy, przez Floriana Suchorabskiego, była zróżnicowana i obfitowała w argumenty zarówno formal-

79 AAP, 174 (wizytacja biskupa Sierakowskiego, dekanat rzeszowski), k. 97, 103-103v; 167 (dekanat jarosławski), 141; Przeworsk Z. 16, s. 812-816 (oblata aktu fundacji kościoła w Ostrowie w 1600 r.).

${ }^{80}$ Tak wielokrotnie, m.in. Przeworsk Z. 37, s. 240.

81 Tamże, s. 240.

${ }^{82}$ Przeworsk Z. 36, s. 1501: praefata episcopalia ipse cittatus et antecessores ipsius semper pro quolibet anno actoribus praefatis solvebant; tamże, s. 1253: episcopalia praefata antecessores cittati et ipse pro quolibet anno ipsis actoribus et antecessoribus semper solvebat [!].

${ }^{83}$ Przeworsk Z. 37, s. 241: alia enim decima manipularis ex agris praedialibus parocho seu rectori ecclesiae penditur, alia vero peccuniaria ex agris censualibus, quas cmethones incolunt, - - alia etenim est decima manipularis, alia est missalium et alia etiam episcopalis; Przeworsk Z. 36, s. 1507-1508: alia est causa nomine missalium plebano - - ratione administrationis sacramentorum per subditos extradi solitis, alia etiam causa ratione solutionis episcopalium vigore supradicti privilegii.

${ }^{84}$ Przeworsk Z. 37 s. 241: et licet quis manipularem ex fundatione ecclesiae proprio rectori dare sit astrictus, tamen et eiusmodi episcopalem vigore eiusdem privilegii et consuetudinis antiquissimae dare et solvere est astrictus.

${ }^{85}$ Przeworsk Z. 36, s. 1261: enim ipse cittatus haeres eorundem bonorum aliqua missalia seu decimam suo ministro alienae religionis ratione administrationis sacramentorum suorum dat, - - solutionem praefatorum episcopalium actoribus ex antiquo servientium - - minime potest subterfugere (nam inter duos acta tertio praeiudicare non possunt).

${ }^{86}$ Przeworsk Z. 37, s. 61: hoc privilegium --compositionem generalem terrae Praemisliensis - - factam esse sine ulla exceptione. 
noprocesowe, jak i merytoryczne oraz historyczne. Owo zróżnicowanie pozwala domyślać się niekiedy wpływu samych pozwanych, a przez to ujawnia poziom ich wiedzy, kultury prawnej i świadomości stanowej. Podkreślić tu należy wyróżniające się bogactwem argumentów stanowisko Jana Pieniążka, człowieka wykształconego na zagranicznych protestanckich uniwersytetach. Z kolei powtarzalność niektórych sformułowań i argumentów przekonuje o istotnym udziale Suchorabskiego w wypracowaniu koncepcji obrony. Pomijając aspekty formalnoprocesowe, niemające znaczenia dla istoty opisywanego zagadnienia, skupimy się na pozostałych zarzutach podnoszonych przez pozwanych, które można ująć w następujące kategorie:

1) Niepodleganie danej wsi obowiązkowi uiszczania dziesięciny biskupiej i brak wiedzy na temat wcześniejszego jej opłacania ${ }^{87}$.

2) Niepodleganie obowiązkowi dziesięcinnemu ludności ruskiej, zamieszkującej daną wieś, ponieważ ugoda biskupa Macieja z mieszkańcami diecezji przemyskiej z 1395 r. dotyczyła jedynie katolików ${ }^{88}$.

3) Bezpodstawność roszczeń kapituły wobec faktu, iż biskupczyzna jako tożsama z mesznym lub dziesięciną z folwarków w tej postaci jest już oddawana miejscowemu plebanowi ${ }^{89}$, oraz wynikające $\mathrm{z}$ tego zakazane prawem podwójne obciążenie danej nieruchomości z tego samego tytułu ${ }^{90}$.

4) Przeniesienie tego świadczenia na miejscowego plebana w związku z ufundowaniem kościoła ${ }^{91}$.

${ }^{87}$ Przeworsk Z. 37, s. 245 (Porudeński): bona illa praesenti oneri nunquam erant subiecta, - - de his vero episcopalibus ne quidem ipsi, sed et patres eorum nesciverunt nec cognoverunt.

${ }^{88}$ Tamże, s. 240 (Pieniążek): quantum vero attinet bona - - ea, cum sint rithus Graeci, nunquam pensioni Romanae subiecta erant nec subiici possint, quandoquidem compositio asserta facta sit inter ordines diocesis Praemisliensis ecclesiae rithus Romani, non autem Roxolanorum; tamże, s. 61 (Derszniak): bona illius recensita non subiacere assertae ordinationi seu compositioni, quandoquidem ex antiquo erant ritus Graeci et nunquam ista episcopalia nuncupata pendebant.

${ }^{89}$ Tamże, s. 245 (Porudeński): bona illa - - semper provisioni ecclesiae villae praefatae et parocho pro tempore existenti studebant, et respectu decimationis ea omnia, quae ex pacto decimae fuerint, pendebant vel pendi solent; tamże, s. 252, 254 (Łowieccy): ipsi suo parocho, qui praeest ecclesiae ibidem sitae, cum subditis suis subiecent et decimam de agris suis pendere solent - - de bonis suprascriptis se pendere decimam seu missalia ex agris censualibus ad ecclesiam parochialem in eisdem bonis - - existentem; Przeworsk Z. 36, s. 1581: ipsi cittati habent suam parrochiam, --ad quam omnes proventus dant ecclesiasticos; Przeworsk Z. 38, s. 151 (Pieniążek): de bonis medietatis oppidi--et ex subditis rithus Romani villarum - - pendere decimam seu missalia ex agris censualibus ad ecclesiam parochialem in eodem oppido - - consistentem.

${ }^{90}$ Przeworsk Z. 37, s. 240 (Pieniążek): duplices enim pensiones et dationes respectu omnibus iuris decimandi solvi non est consuetum; tamże, s. 141-142 (Korniakt): ex quibus agris, si etiam actoribus ista episcopalia nuncupata, que vim decimae manipularis sapiunt, pendi debet, non unam sed tres decimas ex eodem agro ipsius per eundem opere [?] pretium esset.

${ }^{91}$ Przeworsk Z. 36, s. 1500 (Pieniążek): ad solutionem episcopalium sive decimae assertae non teneri nam etenim post eiusmodi compositionem quisque ad usum suum pro edificandis et construendis ecclesiis et instituenda recta et reformata vera religione sanctae religionis ministris remissa pendi solent; Przeworsk Z. 37, s. 248 (Giżyński); post quemquidem privilegium compositionis antecessores cittati ecclesiam in bonis - - errexerunt et proventibus 
5) Przeniesienie świadczenia na ministra protestanckiego z tytułu szafarstwa sakramentów $^{92}$.

6) Niepodleganie temu świadczeniu mieszkańców miast nieposiadających roli, gdyż biskupczyzna jest ekwiwalentem dziesięciny snopowej ${ }^{93}$.

7) Nieadekwatność żądań kapituły opierających się na starych wykazach łanów osiadłych i oczynszowanych, nie zaś aktualnych rejestrach podymnego ${ }^{94}$.

Stanowisko szlachty znalazło najpełniejszą argumentację w wystąpieniu wspomnianego Jana Pieniążka. Stwierdził on, że szlachta zamieszkująca ziemie ruskie została przez króla Kazimierza obdarowana złagodzeniem obciążeń na rzecz Kościoła z powodu konieczności obrony tych ziem. Następnie, że biskup Maciej, nie bacząc na prawa koronne, miał wystarać się o prawo do poboru dziesięcin snopowych, interweniując bezpośrednio w Rzymie (pro et ratione decimae manipularis per

specialibus, quae clerum spectare debent, dotaverunt; tamże, s. 61 (Derszniak): his temporibus, quibus per antecessores suos errecta fuit ecclesia Romani ritus, semper pensionem annuam respectu decimarum coloni illius solvi consueverunt parocho suo. Zarzut ten zapewne miał swoje oparcie w prawie kanonicznym decydującym, że po zaprowadzeniu w diecezji podziału na parafie z mocy prawa dziesięciny winny być oddawane plebanom (S. C h [ o d y ńs ki], Dziesięcina w Polsce, s. 473).

92 Przeworsk Z. 36, s. 1253 (Stadnicki): alio parocho seu ministro - - alienae religionis existenti ratione quorundem administrationis sacramentorum ipsi praestitorum - - cittatus pronunc meminit; tamże, s. 1261 (Porudeński): enim ipse cittatus haeres eorundem bonorum aliqua missalia seu decimam suo ministro alienae religionis ratione administrationis sacramentorum --dat; tamże, s. 1500-1501 (Pieniążek): ipse cittatus rationem [!] administrationis spiritualium, ea quae ex compositionis [!] praefatae pendi debuerunt, ministranti in vera fide apostolica et religionis suae Deo Optimo Maximo fideli pendit et solvit, nec vult eandem pensionem cuius personarum tenetur quandoquidem non decima, sed potius nona seu octava eo ut voluit ordine pendi deberetur, qui enim altari serviunt, ex altare vivunt, qui autem eo negotio servit, ex eodem vivat; tamże, s. 1582; ipsi cittati haerdes et possesores eorundem bonorum praefatorum aliqua missalia seu decimam ministro - - alienis [!] religionis ratione administrationis sacramentorum - - dant. Sprawa przejmowania przez ministrów protestanckich uposażenia zamienianych na zbory kościołów i domaganie się przez nich zwrotu zajętych przez patronów dóbr i świadczeń kościelnych była przedmiotem bez mała każdego synodu w drugiej połowie XVI w., m.in. w Krakowie 1 X 1573, Piotrkowie 1-3 VI 1578 (Cum autem decimae manipulares ab illustrissimis regibus Poloniae et a tota Republica ad conservandum Christi ministerium et promovendam Dei gloriam sunt perpetuo dono donatae, ideo sublato abusu et redeunte ad nos luce veritatis iuste ex debito solvendae sunt et reddendae decimae), czy w Krakowie 21 IX 1579 r. (Akta synodów, t. III, s. 9, 37, 41-43).

${ }_{93}$ Przeworsk Z. 37, s. 238-243 (Pieniążek): non tenetur ad solutionem assertorum episcopalium, quae vim redemptionis decimae manipularis in se continent, incolae vero prefati oppidi agris carent, respectu quorum decimam peccuniarem pendi debent. O słuszności tego stanowiska przekonuje np. zapis z XVIII w., w którym to dziesięciny z ról kmiecych we wsi Rudołowice, nazwane w 1394 r. decima totius villae, określono właśnie jako episcopalia (AAP, 167 [wizytacja biskupa Sierakowskiego], k. 3: vigore tercii privilegii ab ill. Mathia episcopo Praemisliensi accedente venerabilis capituli Praemisliensis consensu anno 1394 ipso die Visitationis rectori ecclesiae episcopalia de villa Rudołowice concessae).

${ }_{94}$ Przeworsk Z. 36, s. 1501 (Pieniążek): tantummodo ex laneis tunc possesionatis, qui ex censu alias residentia apparere possint, solvi debebuntur, tunc temporis non autem ultra. Ideo et ad praesens non nisi ex agris, de quibus Regiae Maiestati census solvendi, scilicet fumalia, eadem decima sex grossorum Bohemicalium solvi debet. 
episcopum Praemisliensem sibi a sede Romana cortisanico more, ut posteribus statutis declaratum est, impetratis) ${ }^{95}$. Ostatecznie biskup w układzie ze szlachtą katolikami (quae est facta cum secularibus ritu seu ordinis Romani ecclesiae, non autem Roxolanis) w 1395 r. zgodził się, aby dobra szlacheckie płaciły ryczałt pieniężny nazywany dziesięciną pieniężną (peccuniam decimalem nuncupari) ${ }^{96}$. Stało się to nie dla uciemiężenia szlachty, toczącej wówczas ciężkie walki zbrojne, lecz dla podniesienia i pomnożenia tych ziem (sed quia compositio praefata non in deteriorem conditionem status nobilitatis Russiae tunc in festam armis pugnationem, sed in illarum terrarum promotionem et locis praesentibus retentionem et augmentum rerum - - facta est $)^{97}$. Świadczeniem tym zostały obciążone tylko osiadłe wówczas i oczynszowane łany, a nie te, które miały w przyszłości zostać zagospodarowane. Dlatego też opłata na rzecz kapituły winna płynąć tylko z tych gruntów, z których jest płacony podatek królewski, tj. podymne. Ten postulat Pieniążka jest niezbyt jasny, gdyż porównując wysokość żądanych w 1590 r. przez kapitułę kwot z szacunkiem zawartym w rejestrze z 1424 r., w większości wypadków stwierdzamy, że kapituła domagała się sum znacznie niższych. Pieniążek twierdził dalej, że po zawarciu układu w 1395 r. każdy szlachcic przekazywał to świadczenie na potrzeby budowanych w swoich dobrach kościołów i na ustanowienie w nich obsługi kapłańskiej oraz jej utrzymanie. Tak więc dziesięcina z łanów oczynszowanych, utożsamiana przezeń z mesznym, a w przypadku mieszczan, nieposiadających gruntów rolnych, z dziesięciną pieniężną, przeszła na miejscowych plebanów lub ministrów protestanckich. Dodatkowo podkreślił, że świadczenie to należy się aktualnym szafarzom sakramentów i duszpasterzom, nie zaś osobom, które zajmują się sprawami świeckimi (qui enim altari serviunt, ex altare vivunt, qui autem eo negotio servit, ex eodem vivat), co było oczywistym przytykiem pod adresem kanoników, oraz że wysokość świadczenia zależy od uznania płacącego, czy będzie to dziesięcina, czy dziewiąta lub nawet ósma część dochodu ${ }^{98}$. Pobrzmiewają tu echa uchwał synodów różnowierczych, np. tego odbytego w Książu w 1560 r., gdzie postanowiono: „Iżby z JKM jednano było co najrychlej o tych duchowieństwach [uposażeniach], które bierzą papieżnicy, a żadnej prace w kościelech tych nie wiodą, iżby też onych beneficyj nie brali etc.”, czy we Włodzisławiu z tegoż roku, gdzie uchwalono sposób zbierania pieniędzy na cele parafialne, akcentując dowolność wysokości danin składanych przez patronów: Primo pastor pro pietate et facultate conferat certam sumam, deinde patroni iuxta voluntatem suam $^{99}$. Dalej Pieniążek dowodził, że dziesięcina biskupia, będąca w rzeczywistości ryczałtowym ekwiwalentem dziesięciny snopowej, jest dodatkowym obciążeniem, a to jest niezgodne z prawem, niedopuszczającym podwójnego obciążenia jakiegoś

${ }_{95}$ Przeworsk Z. 36, s. 1500 (1591 r.).

96 Tamże.

97 Tamże.

98 Tamże, s. 1499-1502.

99 Akta synodów, t. II, s. 60, 206. Inna sprawa, że w uchwałach synodalnych wielokrotnie pojawiają się odwołania do Pisma Świętego i przekazanego w nim Boskiego nakazu oddawania dziesięciny: Deus ipse pro sua iustitia lege sua sancivit modumque sui ministerii conservandi mandavit, dicens: Decimas tuas et primicias tuas non tardabis reddere mihi oraz omnes decimae de fructibus terrae Domini sunt (Akta synodów, t. III, s. 42). 
podmiotu z tytułu tej samej powinności. Rolniczy charakter tej daniny powoduje też, jak stwierdził, że nie są do jej płacenia zobowiązani mieszkańcy miast, nieposiadający gruntów uprawnych.

Pozostali pozwani, bez względu na wyznanie, w swojej obronie wykorzystywali tylko część z wyróżnionych argumentów, a niekiedy tylko pojedyncze z nich. Najczęściej wskazywali na fakt identyczności dziesięciny biskupiej z którymś z uiszczanych miejscowym plebanom lub ministrom świadczeń (mesznym lub dziesięciną z folwarków), podnosząc niedopuszczalność podwójnego czy nawet potrójnego obciążenia tej samej nieruchomości (5 razy). Znacznie rzadziej (2 razy) podniesiono fakt niepodlegania ludności ruskiej obowiązkowi dziesięcinnemu na rzecz Kościoła łacińskiego.

W większości omawianych tutaj spraw sąd ziemski przychylił się do argumentacji pozwanych, stwierdzając, że biskupczyzna nie została ustanowiona jako dodatkowe świadczenie, ale że jest ekwiwalentem dziesięciny z dóbr szlacheckich, a zatem niedopuszczalne jest podwójne obciążanie kogoś z tego samego tytułu (ex privilegio quidem compositionis divi olim Vladislai regis constat pensionem episcopalem non ultra onus pendendarum decimarum bonis nobilium impositam esse, sed pro decima et ratione decimae bonis nobilium impositam esse, et peccuniam decimalem nuncupari, ob idque duplici onere, et decimae, et huiusmodi episcopalium quempiam affici non posse) i udzielał pozwanym odroczenia dla udowodnienia, że z ról oczynszowanych w danej wsi meszne pobiera miejscowy pleban: ad munimenta - -, quibus probabunt, de bonis suprascriptis se pendere decimam seu missalia ex agris censualibus ad ecclesiam parrochialem ${ }^{100}$. Pełnomocnik kapituły odwoływał się do Trybunału Koronnego, składając jednocześnie naganę sędziego (motio). Przyznać należy w tym względzie słuszność kapitule, gdyż sędzia Jan Jaskmanicki, protestant, skonfliktowany od lat z kapitułą, wyraźnie faworyzował pozwanych ${ }^{101}$.

Trybunał Koronny rozsądził opisywane tutaj sprawy dopiero przed lutym $1596 \mathrm{r}$. Nie znamy dalszego ciągu trzech postępowań (z Łowieckimi, Stanisławem Porudeńskim i Mikołajem Giżyńskim). W pozostałych czterech Trybunał, nie wdając się w analizę natury prawnej biskupczyzny ani uwarunkowań historycznych jej wprowadzenia, uchylił wyroki pierwszej instancji, przyznając rację kapitule, że z mocy przywileju 1395 r. mieszkańcy ziemi przemyskiej zobowiązani są do płacenia biskupczyzny w zamian za dziesięcinę snopową (apparet ex privilegio - - incolas terrae Praemisliensis ea episcopalia teneri solvere ratione decimae manipularis pro decima ${ }^{102}$ i nakazał kapitule złożenie przysięgi przez dwóch kanoników z dwoma szlachty, że była zawsze w posiadaniu dziesięcin z osad wyszczególnionych w pozwach. Sprawy wróciły więc do sądu w Przeworsku, gdzie jesienią tego samego roku pozwani w większości odstąpili od egzekwowania od kanoników przysięgi i przyjęli wyrok

100 Przeworsk Z. 37, s. 124 (Kostczanki), 144 (Korniakt), 242 (Pieniążek), 249-250 (Giżyński), 253-254 (Lowieccy).

${ }^{101}$ W 1590 r. kapituła na prośbę wikariuszy katedralnych zdecydowała się wystosować do niego pismo wzywające go do uiszczenia zaległej od pięciu lat dziesięciny z folwarku w Jaskmanicach (AAP, nr II, k. 216).

102 Przeworsk Z. 38, s. 229-231 (Stadnicki). 
nakazujący im zapłacenie zaległych świadczeń ${ }^{103}$. Sąd zalecił im na przyszłość regularne uiszczanie tej należności ${ }^{104}$.

Sprawa świadczeń na rzecz kapituły katedralnej przemyskiej wywołała zdecydowany opór pewnej, dość nielicznej zresztą, grupy miejscowej szlachty, zróżnicowanej pod względem majątkowym i wyznaniowym. Dodatkowych, w odczuciu pozwanych, obciążeń usiłowali uniknąć zarówno protestanci, jak i katolicy, co uzasadnia ostrożność w traktowaniu każdego konfliktu z Kościołem jako przejawu odstępstwa od religii katolickiej. Niemniej analizowany tutaj spór wpisuje się rzeczywiście w szerszy kontekst walki szlachty o egzekucję praw i zmniejszenie zależności od Kościoła. Kilkuletni proces zakończył się wygraną strony kościelnej. Trybunał Koronny, który ostatecznie rozstrzygał wszystkie opisane sprawy, nie wnikając w jej złożoną materię i uwarunkowania historyczne, przyjął za podstawę literalną wykładnię dokumentu Władysława Jagiełły. W efekcie wszyscy pozwani przyjęli wyrok trybunalski i uregulowali zaległe należności wobec kapituły. Był to ostatni już akord trwających przez prawie cały XVI w. sporów szlachty czerwonoruskiej z Kościołem, podsycanej okresowo nowinkarstwem religijnym.

\section{BIBLIOGRAFIA}

Abraham W., Powstanie organizacji kościoła łacińskiego na Rusi, t. I, Lwów 1904.

Blajer W., Pradzieje i wczesne średniowiecze okolic Pruchnika, w: Pruchnik. Studia z dziejów miasta i okolic, wyd. 2, Kraków 2017.

Boniecki A., Herbarz polski, t. XV, Warszawa 1912.

Chodyński S., Dziesięcina w Polsce, w: Encyklopedia kościelna, wyd. M. Nowodworski, t. IV, Warszawa 1874.

${ }^{103}$ Od wymogu przysięgi odstąpił 5 II 1596 r. Pieniążek, a 17 IX 1596 r. Korniakt (Przeworsk Z. 38, k. 150-154, 224-227); tego samego dnia woźny oświadczył, że wysłuchał przysięgi kanoników w sporze ze Stadnickim, a wówczas ten zapłacił należne sumy i został uwolniony od pozwu i sprawy (tamże, s. 229-231); dopiero 3 VIII 1599 r. Katarzyna żona Adama Hieronima Sieniawskiego odstąpiła od wymogu przysięgi, Anna żona Aleksandra Ostrogskiego zażądała zaś jej złożenia (tamże, s. 1153-1157). O odstępowaniu przez strony procesowe od zasądzonej przysięgi m.in. w obawie przed świętokradztwem zob. A. M o n i u s z k o, Iuramentum corporale praestitit. Przyczynek do badań nad przysięgą dowodową w koronnym procesie ziemskim u schyłku XVI wieku, Соціум. Альманах соціальної історії 9, 2010, s. 371, oraz N. S t a r c h e n k o, Oath as an evidential tactic in the legal procedure in Volhynia: legislation and practice (1566 - early 17th century), w: Lietuvos statutas: Temidès ir klejos teritorijos. Straipsnių rinkinys, Vilnius 2017, s. 259-279. Ciekawe świadectwo w tej kwestii przynoszą akta synodu protestanckiego w Poznaniu z 1 XI 1560 r., w których zanotowano, „że przysięga dla prawdy i sprawiedliwości grzechem nie jest, ale z dopuszczenia Bożego, a zwłaszcza w prawie, gdy ją komu dekretem przysądzą. A iż w statucie przysięga jest opisana tak: Wzywając na pomoc świętych i dwa palce położywszy na drewnie, tego bałwochwalstwa ma się wierny wystrzegać" (Akta synodów, t. II, s. 69).

${ }_{104}$ Trzech jednak spośród owych napomnianych nie zastosowało się do tych zaleceń. Byli to pełnomocnik większości pozwanych, miecznik przemyski Florian Suchorabski (Przeworsk Z. 38, s. 784-785), Stanisław Stadnicki (tamże, s. 592-593, 788-790, 981-985, 1108-1109, 1255-1260) i Konstanty Korniakt (tamże, s. 593), którzy w 1. 1597-1598 ponownie zostali pozwani przez kapitułę o zaleganie z płatnością dziesięcin za okres od 1591 do 1597 r. Dnia 16 IX 1597 r. Łojecki w imieniu kapituły skwitował Korniakta z zaległej biskupczyzny z 14 lat, tj. od 1583 do 1597 r. (Przeworsk Z. 16, s. 278). 
Dąbkowski P., Podział administracyjny województwa ruskiego i bełzkiego w XV wieku, Lwów 1939.

Dudziak J., Dziesięcina, w: Encyklopedia Katolicka, t. IV, Lublin 1985.

Dworzaczek W., Leliwici Tarnowscy. Z dziejów możnowładztwa małopolskiego. Wiek XIV-XV, Warszawa 1971.

Fastnacht A., Osadnictwo ziemi sanockiej w latach 1340-1650, Wrocław 1962.

Gąsiorowski A., Itinerarium króla Władysława Jagiełły 1386-1434, Warszawa 1972.

Janeczek A., Osadnictwo pogranicza polsko-ruskiego. Województwo bełskie od schyłku XIV do początku XVII wieku, Warszawa 1993.

Kaczmarczyk Z., Monarchia Kazimierza Wielkiego, t. II, Poznań 1946.

Kaczmarczyk Z., Polska czasów Kazimierza Wielkiego, Kraków 1968.

Kallenbach J., Polacy w Bazylei w XVI wieku, w: Archiwum do dziejów literatury i oświaty w Polsce, t. VI, Kraków 1890.

Karczewski D., Uwagi o początkach osadnictwa klucza łańcuckiego (druga połowa XIV wieku), w: Narodziny Rzeczypospolitej. Studia z dziejów średniowiecza i czasów wczesnonowożytnych, Kraków 2012.

Klebowicz G., Organizacja parafialna diecezji przemyskiej obrządku łacińskiego w XIV-XVI wieku, Lublin 2013.

Kurtyka J., Osadnictwo średniowieczne. Początki osady i miasta, w: Dzieje Rzeszowa, t. I, Rzeszów 1994.

Kwolek J., Borukowski Jan z Bielina, w: Polski słownik biograficzny, t. II (1936).

Łoziński W., Prawem i lewem. Obyczaje na Czerwonej Rusi w pierwszej połowie XVII wieku, wyd. 6, Kraków 1960.

Matuszewski J., Missalia - mensalia, w: Cultus et cognitio. Studia z dziejów średniowiecznej kultury, Warszawa 1976.

Moniuszko A., Iuramentum corporale praestitit. Przyczynek do badań nad przysięgą dowodową w koronnym procesie ziemskim u schyłku XVI wieku, Соціум. Альманах соціальної історії 9, 2010.

Morawski M., Synod piotrkowski w roku 1589, Włocławek 1937.

Nagielski M., Sieniawski Adama Hieronim, w: Polski słownik biograficzny, t. XXXVII (1996).

Paszkiewicz H., Polityka ruska Kazimierza Wielkiego, Warszawa 1925.

Starchenko N., Oath as an evidential tactic in the legal procedure in Volhynia: legislation and practice (1566 - early 17th century), w: Lietuvos statutas: Temidès ir klejjos teritorijos. Straipsnių rinkinys, Vilnius 2017.

Strzelecka A., Maciej (zm. 1420), kanclerz królowej, biskup przemyski, w: Polski słownik biograficzny, t. XIX (1974).

Szyszka J., Kształtowanie się podziałów terytorialnych Rusi Czerwonej na przykładzie ziemi lwowskiej, Średniowiecze Polskie i Powszechne 3 (7), 2011, s. 120-140.

Śliwa T., Kolegium prałatów i kanoników rzymskokatolickiej kapituły przemyskiej w latach 1500-1525, Przemyśl 2016.

Tomkowicz S., Metrica nec non liber nationis Polonorum, w: Archiwum do dziejów literatury i oświaty w Polsce, t. II, Kraków 1882.

Trajdos T. M., Kapituła katedry przemyskiej i kuria biskupia w czasach Władysława Jagiełły, Przegląd Historyczny 88, 1997, z. 3-4, s. 383-415.

Trajdos T. M., Miechowici na ziemi przemyskiej za panowania Władysława II Jagiełły, Folia Historica Cracoviensia 4-5, 1997-1998.

Windakiewicz S., Księga nacji polskiej w Padwie, w: Archiwum do dziejów literatury i oświaty w Polsce, t. VI, Kraków 1882.

Wolff J., Kniaziowie litewsko-ruscy od końca czternastego wieku, Warszawa 1895.

Wolski M., Dzieje miasta i okolic, w: Pruchnik. Studia z dziejów miasta i okolic, wyd. 2, Kraków 2017.

Wolski M., Reformacyjny epizod w historii Pruchnika, w: Fontes et historia. Prace dedykowane Antoniemu Gąsiorowskiemu, Poznań 2007. 
Wolski M., O początkach kościoła i parafii w Tuligłowach. Przyczynek do historii struktur Kościoła łacińskiego w diecezji przemyskiej, Roczniki Historyczne 83, 2017.

Wolski M., Blajer W., Zanikłe miejscowości w okolicach Pruchnika w dawnej ziemi przemyskiej, w: Wieś zaginiona. Stan i perspektywy badań, Gliwice 2016.

Wyszyński M., Ze studiów nad historią dziesięciny w Polsce średniowiecznej, t. I: Czasy Władysława Łokietka i Kazimierza W., Lwów 1929.

\section{The dispute of the cathedral chapter in Przemyśl with the nobles concerning episcopal tithe in the second half of the $16^{\text {th }}$ century}

\section{Summary}

From the beginning of the existence of organisational structures of the Catholic Church in Red Ruthenia, obligations to it differed from those in other dioceses. The royal policy of abatements for the settlers coming from the west and difficulties related to recent the incorporation into the Crown of those culturally, confessionally and socially foreign lands were the reasons why obligations towards the Church were lower and the sheaf tithe, common in all other Polish regions, was not applied. Instead of it, a lump sum from every peasant field was introduced, called the bishop's share. In the diocese of Przemyśl it was first levied in differentiated quantity, but eventually it became unified at six wide grosches from one field. At the turn of the $14^{\text {th }}$ and $15^{\text {th }}$ centuries part of those tithes were granted by bishops of Przemyśl to the cathedral chapter. Already in the $15^{\text {th }}$ century there were problems with levying them. In the second half of the $16^{\text {th }}$ century the rising status awareness of the nobility, their political ambitions and influence of the Reformation led to increasing controversies over the tithes. Also part of the Przemyśl nobility, irrespective of religious denomination, refused to pay the tithe to the Church, including the bishop's share for the cathedral chapter. As a result, in 1590 the chapter brought 26 cases before the land court in Przeworsk. The defense used many legal, historical and religious arguments. After six years of the process, the Crown Tribunal decreed that the chapter was right. This was the last mass appearance of the Ruthenian lands nobility against the Catholic Church. 